\title{
Zabójstwo króla Aleksandra I w świetle archiwalnych relacji prasowych
}

Zarys treści: W artykule omówiono uwarunkowania, przyczyny, przebieg i wczesne konsekwencje morderstwa dokonanego na monarsze jugosłowiańskim w październiku $1934 \mathrm{r}$. w Marsylii. Skoncentrowano się również na opisie sytuacji wewnętrznej w Jugosławii po śmierci króla Aleksandra I, a także na przesłankach kształtowania się relacji pomiędzy Królestwem Karadziordziewiczów a środowiskiem międzynarodowym. Zabójstwo monarchy jugosłowiańskiego było dotąd omawianie w literaturze w sposób ogólny, podczas gdy szczegółowe okoliczności zbrodni dokonanej przez Włado Czernozemskiego świadczyły o licznych nieprawidłowościach i szerokiej intrydze zawiązanej wokół wizyty króla Aleksandra I we Francji.

Outline of content: The article discusses the reasons for, circumstances, course of action and early consequences of the assassination of King Alexander I of Yugoslavia in October 1934 in Marseilles, France. There is also a focus on the description of Yugoslavia's internal situation after King Alexander I's death, as well as on the factors contributing to the relations between the Kingdom of the Karađorđevićs and the international arena. Thus far, the assassination of the Yugoslavian monarch has been discussed in a very general way, while the specific circumstances of the murder committed by Vlado Chernozemski revealed numerous irregularities and a broad plot constructed around the king's visit to France.

Słowa kluczowe: Jugosławia Karadziordziewiczów, Jugosławia w okresie międzywojennym, Królestwo Jugosławii, król Aleksander I, zabójstwo króla Aleksandra I w 1934 r.

Keywords: Karađorđevićs Yugoslavia, Kingdom of Yugoslavia in interwar period, King Alexander I, assassination of King Alexander I in 1934

\section{Wstęp}

Wydarzenia wczesnej jesieni 1934 r. nie zapowiadały zmian w Królestwie Jugosławii. Od prawie sześciu lat, wskutek przewrotu dokonanego w styczniu 1929 r. ${ }^{1}$,

${ }^{1}$ Dokładnie 6 stycznia 1929 r. król Aleksander I, w zasadzie stojący dotąd w cieniu, dokonał 
rzeczywistą władzę w państwie sprawował król Aleksander I z dynastii Karadziordziewiczów. Ówczesny model rządów tego monarchy można by określić mianem autorytarnego, choć król Aleksander I starał się zachowywać pozory demokracji. Oto bowiem w październiku 1929 r. monarcha przeprowadził reformę administracyjną państwa, we wrześniu 1931 r. ustanowił konstytucję jugosłowiańską i jeszcze tej samej jesieni zorganizował wybory parlamentarne, a także przywrócił działalność wcześniej zdelegalizowanego parlamentu. Na kolejne lata król Aleksander I zapowiadał stopniowe odmrażanie swoich autorytarnych rządów i przywrócenie pełnej demokracji w państwie, ale do października 1934 r. obietnice te nie zostały spełnione.

Trzeba jednak zwrócić uwagę, że w okresie silnych rządów króla Aleksandra I sytuacja Królestwa Jugosławii na arenie międzynarodowej kształtowała się korzystnie. Pomimo zatargu z Włochami rządzonymi przez Benito Mussoliniego Jugosławia umacniała swoją pozycję poprzez sojusze w Europie Środkowej i na Bałkanach z Czechosłowacją, Rumunią, Grecją i Turcją (w ramach bloków tzw. Małej Ententy oraz Ententy Bałkańskiej), a także pielęgnowała politykę sojuszniczą wobec Francji. W każdym razie poważnym problemem króla Aleksandra I były nastroje wewnątrz Jugosławii, szczególnie wśród Chorwatów, którzy metodami politycznymi lub terrorystycznymi domagali się autonomizacji lub zupełnego oderwania ziem chorwackich od Królestwa Karadziordziewiczów.

Monarcha zaplanował więc uregulowanie kwestii separatyzmów chorwackich w państwie poprzez ułożenie się z politycznym liderem Chorwatów. Był nim Władko Maček, spadkobierca tradycji partii chorwackich ludowców, który od kwietnia 1933 r. pod zarzutem działalności antypaństwowej przebywał w więzieniu. Król Aleksander I nie zdradził, w jaki sposób planuje ułożyć się z Mačkiem, ale plany pokojowego rozstrzygnięcia sporu wewnętrznego w Jugosławii nie doczekały się realizacji, ponieważ monarcha został zastrzelony 9 października 1934 r. podczas pobytu we Francji. Wraz z jego śmiercią de facto załamała się idea państwa jugosłowiańskiego realizowana przez Karadziordziewiczów, a w kraju zapanował chaos. Z tego też powodu okoliczności zabójstwa króla Aleksandra I wydają się tematem interesującym, choć dotąd nie zostały dostatecznie omówione, szczególnie jeśli wziąć pod uwagę polskie i nie-bałkańskie opracowania naukowe.

Zatem celem tego artykułu jest omówienie przebiegu zamachu, w którym zginął król Aleksander I, a także opis związanych z tym wydarzeniem okoliczności i wczesnych konsekwencji, wśród których szczególną uwagę należy zwrócić na charakterystykę zamachowca, przesłanki śledztwa międzynarodowego w sprawie zamachu, i wreszcie sytuację wewnętrzną w Jugosławii po śmierci króla Aleksandra I.

bezkrwawego przewrotu w państwie. Monarcha przy wsparciu zaufanych elit politycznych i wojskowych zdelegalizował wszystkie partie polityczne, a także zawiesił parlament i konstytucję Jugosławii. W sumie na mocy jednej decyzji w ówczesnym Królestwie SHS dokonała się de facto zmiana ustroju - monarchię parlamentarną zastąpiono dyktaturą króla. 
Wiodącym źródłem, które posłużyło do opracowania artykułu były serbskie ${ }^{2}$ i polskie $^{3}$ relacje prasowe opublikowane $\mathrm{w}$ okresie zamachu, a także nieliczne opracowania dotyczące omawianego wydarzenia ze szczególnym uwzględnieniem wspomnień polskiego urzędnika konsularnego Jana Meysztowicza.

Wyniki badań zostały zweryfikowane i poddane przez autora analizie w oparciu o ustalenia zawarte we współczesnej literaturze przedmiotu opracowanej na ogół przez bałkańskich autorów wymienionych w wykazie źródeł i literatury. W przypadku braku takowych - co było dość częstą przypadłością w zakresie omawianej problematyki - autor zweryfikował swoje ustalenia w oparciu o dokumenty archiwalne, a także poprzez ocenę wiarygodności cytowanych tytułów prasowych. Tłumaczenia zawarte $\mathrm{w}$ artykule zostały sporządzone przez autora.

\section{Przebieg zamachu}

Oficjalnym celem trzydniowej wizyty króla Aleksandra I we Francji było umocnienie stosunków pomiędzy Małą Ententą a Francją ${ }^{4}$. Bezpośredni świadek zabójstwa króla Aleksandra I, ówczesny polski urzędnik konsularny w Marsylii, Jan Meysztowicz ${ }^{5}$ zwrócił też uwagę na włoski kontekst tej wizyty, twierdząc, iż to właśnie Francuzi dążyli do złagodzenia napiętych stosunków pomiędzy Jugosławią a Włochami. Francuskiemu rządowi Gastona Doumergue’a, planującemu współdziałanie na arenie międzynarodowej, zależało bowiem na pozyskaniu sympatii Mussoliniego ${ }^{6}$.

W podobnym tonie wizytę króla Aleksandra I komentowano w polskich gazetach. Na łamach „Dziennika Poznańskiego” zauważono, iż Francja przyjęła rolę pośrednika pomiędzy Jugosławią a Włochami. Rokowania tych państw zapowiadały się obiecująco, o czym świadczyła wygłoszona przez Mussoliniego deklaracja o chęci porozumienia się z monarchą jugosłowiańskim. W każdy razie to nie Il Duce dążył do naprawy stosunków włosko-jugosłowiańskich, ale przede wszystkim Francuzi. Wypowiedź wpływowego senatora Henry'ego Bérengera klarownie odzwierciedliła nastroje francuskiej klasy politycznej w tej sprawie: „Nadszedł czas, aby pochwycić

2 Trzeba tu zauważyć, że w 1934 r. najbardziej wiarygodnym źródłem prasowym w Królestwie Jugosławii była gazeta „Политика” („Politika”). Dziennik nie poddał się zupełnie wpływom dworu Karadziordziewiczów w okresie rządów króla Aleksandra I, a artykuły w nim publikowane często zawierały relacje niezależnych korespondentów działających w najważniejszych państwach.

${ }^{3}$ Cytowane $\mathrm{w}$ tekście polskie relacje prasowe w zasadniczej części stanowiły przekłady $\mathrm{z}$ wiodących tytułów francuskich i innych europejskich gazet.

${ }^{4}$ Arhiv Jugoslavije w Belgradzie (dalej: АJ), Свијем, год. 7, кљ. 13, бр. 22, sygn. 7-13-22, Краль Александар разговара са управнииом франиуске школе у Београду после помена Полу Dумеру, 12 мај 1932.

${ }^{5}$ Polskim konsulem w Marsylii, a więc i przełożonym Meysztowicza, był wówczas Witold Obrębski.

${ }^{6}$ J. Meysztowicz, Czas przeszły dokonany. Wspomnienia ze służby w Ministerstwie Spraw Zagranicznych w latach 1932-1939, przedmowa H. Batowski, Kraków 1984, s. 73. 
nadarzającą się sposobność porozumienia Włoch, Jugosławii i Francji dla wspólnej obrony pokoju. Przez wspólne i wzajemne poszanowanie honoru i praw każdej ze stron musi być przywrócone to porozumienie. Serbia i Włochy walczyły razem na ziemi francuskiej, a Francja walczyła u ich boku o wszystkich tych narodów wyzwolenie. Wynik tego był dość wspaniały na to, aby rywalizacja prestiżu ich wpływów mogła go zaciemnić i wyjałowić"7.

Jeszcze w dniu zabójstwa monarchy jugosłowiańskiego na łamach „Ilustrowanego Kuryera Codziennego" opublikowano artykuł, w którym opisane zostały francuskie przygotowania do wizyty króla Aleksandra I. Według tego artykułu zarówno rząd Gastona Doumergue'a, jak również prezydent Francji Albert Lebrun, pragnęli nadać przyjazdowi monarchy wyjątkowy charakter ${ }^{8}$. Na łamach krakowskiej gazety poinformowano, że prezydent Lebrun będzie oczekiwał na monarchę na dworcu w Paryżu. Opisując cel wizyty, powołano się na ministra spraw zagranicznych Francji, Louisa Barthou, który „zapewnia, że cała Francja z entuzjazmem powita bohatera narodowego, króla Aleksandra, gdyż Francja świadoma jest siły i znaczenia przyjaźni Jugosławii, przyjaźni wykutej w ogniu walki o egzystencję obu narodów. Francja i Jugosławia ożywione są jednym i tym samym pragnieniem utrzymania trwałego pokoju i szczerej, lojalnej współpracy"9.

Król Aleksander I przypłynął do Francji około godziny 16.00 na pokładzie kontrtorpedowca o nazwie Dubrownik. W niedużej odległości od brzegu z okrętu zrzucono kotwicę. Następnie do burty Dubrownika zbliżyło się kilka motorówek. Do jednej z nich wsiadł monarcha, zaś do następnych oficerowie francuscy oraz świta królewska, w tym m.in. minister spraw zagranicznych Jugosławii, Bogoljub Jewticz. Motorówki ruszyły w kierunku tzw. Starego Portu w Marsylii ${ }^{10}$. W tym czasie królowa Maria, małżonka króla Aleksandra I, podróżowała do Francji koleją ${ }^{11}$. Następnie miała oczekiwać przyjazdu monarchy we francuskim Dijon, a więc w mieście położonym na trasie pomiędzy Marsylią a Paryżem ${ }^{12}$.

Po opuszczeniu motorówki przez monarchę Meysztowicz zwrócił uwagę na jego wspaniały, admiralski mundur, który ozdobiła Wielka Wstęga Legii Honorowej ${ }^{13}$. W marsylskim porcie przy Quai des Belges Aleksandra I powitała uroczysta delegacja, na czele której stanął minister spraw zagranicznych, Louis Barthou jako przedstawiciel rządu francuskiego oraz generał Alphonse Joseph Georges reprezentujący armię francuską. W trakcie oficjalnego powitania króla jugosłowiańskiego

7 Jakie motywy kierowały zbrodniarzem?, „Dziennik Poznański” 233 (11.10.1934), s. 1.

${ }^{8}$ Francja przygotowuje wielkie uroczystości ku czci króla Jugosławji, „Ilustrowany Kuryer Codzienny” 280 (9.10.1934), s. 3.

9 Ibidem.

${ }^{10}$ J. Meysztowicz, op. cit., s. 76.

11 Królowej doskwierała choroba morska, w rezultacie czego była zmuszona opuścić pokład Dubrownika krótko po wypłynięciu z wód jugosłowiańskich.

12 Ж. Петровска, Атентатот во Марсеј, „Македонска нација”, http://www.mn.mk/aktuelno/496 (dostęp: 5.03.2014).

13 J. Meysztowicz, op. cit., s. 76. 
niesmak Meysztowicza wywołały niezbyt korzystnie prezentująca się orkiestra wojskowa oraz kompania honorowa piechoty francuskiej, które stanowiły ważną część delegacji powitalnej. Polski urzędnik dyplomatyczny zauważył nieodpowiednio utrzymane mundury i przestarzałą broń. Opisując swoje wrażenia, Meysztowicz nieco ironicznie stwierdził: „Może chodzi [...] o wytworzenie nastroju przypominającego wielką wojnę, której wszak bohaterem na froncie serbskim był właśnie Aleksander" ${ }^{\prime 4}$. Okazało się jednak, że było to najlepsze wyposażenie, jakim wtedy dysponowano w Marsylii ${ }^{15}$.

Po oficjalnym przywitaniu władca jugosłowiański wraz z delegacją francuską wsiadł do otwartego samochodu rządowego firmy Delage, który w powolnym tempie ruszył ulicami Marsylii. Minister Louis Barthou usiadł po lewej stronie króla, zaś generał Alphonse Joseph Georges - naprzeciwko niego. Samochód poruszał się z prędkością przewidzianą w protokole uroczystości, a więc dokładnie $8 \mathrm{~km} / \mathrm{h}$. Pojazdem kierował szofer o nazwisku Berteleni ${ }^{16}$.

Pierwszym celem przejazdu samochodu był stojący przy bulwarze La Corniche pomnik, który upamiętniał żołnierzy poległych na froncie wschodnim w czasie wojny światowej. Monarcha miał tam złożyć wieniec, co zresztą było jego inicjatywą podjętą jeszcze przed przyjazdem do Marsylii. Zgodnie z planem samochód ruszył w górę ulicy Canebière, zmierzając na ulicę Saint-Ferréol. Politykom towarzyszyła obstawa konnej żandarmerii francuskiej, tzw. Gardes Mobiles, pod dowództwem pułkownika Jules'a Piolleta ${ }^{17}$. Przed samochodem ruszyła kawalkada osiemnastu oficerów policji marsylskiej, za pojazdem podążali dwaj żandarmi konni z Gardes Mobiles, a za nimi jechały samochody z oficjelami i świtą króla ${ }^{18}$. Licznego tłumu, żywiołowo wiwatującego na cześć monarchy, strzegły jednostki policji oraz specjalnie oddelegowany oddział żołnierzy armii francuskiej, tzw. Tirailleurs Sénégalais. Liczba wszystkich funkcjonariuszy wynosiła około półtora tysiąca. Byli oni rozstawieni co sześć metrów. Meysztowicz zwrócił uwagę, że zarówno policja, jak i żołnierze stali zwróceni twarzami do samochodu, a nie do tłumu $^{19}$. Można zatem zauważyć, że bezpośrednia ochrona króla i delegacji francuskiej była zorganizowana w sposób dalece nieprofesjonalny, biorąc pod uwagę nawet ówczesne standardy bezpieczeństwa ${ }^{20}$.

14 Ibidem, s. 75.

${ }^{15}$ Ibidem.

16 Imię nieustalone. Zob. Ж. Петровска, op. cit.

17 L'Assassinat du Roi Alexandre et de M. Barthou, „Le Petit Parisien” 21043 (10.10.1934), s. 3.

18 W pierwszym samochodzie za królem Aleksandrem I, ministrem Barthou oraz generałem Georgesem znajdował się minister Jewticz, który dzięki temu mógł obserwować przebieg zamachu. Jako pierwszy znalazł się też przy konającym królu. Zob. Ж. Петровска, op. cit.

19 J. Meysztowicz, op. cit., s. 77.

20 Autor opisał okoliczności zamachu na podstawie dzienników Meysztowicza, a także trzyminutowego filmu Alexander Murdered, nakręconego przez Georgesa Mejata w chwili zabójstwa. Film zyskał później światowy rozgłos dzięki ogólnoświatowej emisji Grahama McNamee w ramach Universal Newsreel. 
Sam moment zamachu Meysztowicz opisał tymi słowami:

Kilkadziesiąt metrów od Starego Portu, na wysokości gmachu giełdy, jakiś mężczyzna wybiegł z pierwszych rzędów zebranych na trotuarze, wskoczył na stopień samochodu i prawie dotykając lufą swych ofiar opróżnił jedną serią magazynek wielkiego 10-strzałowego mauzera. [...] Cała scena trwała kilkanaście sekund. Szybkość działania zabójcy świadczyła, że był dobrze wyszkolony w operowaniu pistoletem automatycznym. Śmiertelnie ranny król osunął się na siedzenie samochodu, gen. Georges trafiony trzema kulami, jedna z nich utkwiła w piersi, stracił przytomność. Minister Barthou lekko ranny w przegub ręki wysiadł z samochodu o własnych siłach ${ }^{21}$. Policjanci i Gardes Mobiles zaczęli strzelać z pistoletów raczej na oślep, zabijając jedną osobę i raniąc kilka spośród publiczności na trotuarach. Zamachowiec naszpikowany kulami i zmasakrowany butami leżał martwy na jezdni. Wszyscy oficjele stracili do tego stopnia głowy, że minęło parę minut, zanim zaopiekowano się rannym Barthou. [...] Zabiegi lekarskie i transfuzję zastosowano za późno. Siedemdziesięciodwuletni Barthou zmarł na skutek upływu krwi. Generała Georges’a udało się uratować22.

Przytoczony opis Meysztowicza zawiera pewne nieścisłości i niedomówienia spowodowane chaosem ówczesnych wydarzeń. Otóż zamachowiec do wykonania swej zbrodni użył pistoletu półautomatycznego mauzer C96, który został przez niego ukryty pod bukietem kwiatów ${ }^{23}$. Zamachowiec, zbliżając się do monarchy, zasugerował chęć wręczenia mu bukietu, jednocześnie wykrzykując w języku francuskim słowa: „Niech żyje król!”. Następnie z bliskiej odległości strzelił dziesięć razy, przy czym najwięcej pocisków raziło monarchę i generała ${ }^{24}$. Na łamach „Ilustrowanego Kuryera Codziennego" ustalono, że w trakcie zamachu padło trzydzieści strzałów, a więc około dwudziestu zostało oddanych przez policję ${ }^{25}$.

Przebieg zamachu opisał również pułkownik Jules Piollet:

Samochód wiozący króla Aleksandra oraz ministra Barthou i generała Georgesa znajdował się właśnie przed gmachem giełdy, gdy nagle zauważyłem, że jakiś mężczyzna wyskoczył z tłumu i strzeliwszy do zagradzającego mu drogę policjanta, przebiegł obok mego konia, wskoczył na stopnie samochodu i rozpoczął strzelać [...] Spiąłem konia ostrogami, ale chociaż zaraz znalazłem się przy zamachowcu, zdołał on już dać swe zbrodnicze strzały, zanim ciąłem go szablą przez głowę [...] Morderca, pomimo że leżał już ciężko ranny na ziemi, nie przestał strzelać. Kule jego trafiły jeszcze dwóch policjantów oraz kilka osób z tłumu [... $]^{26}$.

${ }^{21}$ Oszołomionego ministra Barthou, tuż po jego wyjściu z samochodu, można bez trudu zauważyć na wspominanym wcześniej filmie.

22 J. Meysztowicz, op. cit., s. 77-78.

23 Dokładne wymiary broni: długość - 28,8 cm (wraz z kolbą - 63,3 cm), waga - 1,24 kg. Ówczesna wartość takiego modelu mauzera wynosiła 500 franków francuskich. Broń zamachowca znajduje się obecnie w Muzeum Narodowym w Belgradzie. Wyrok śmierci na króla Aleksandra, „Ilustrowana Republika” 281 (12.10.1934), s. 2; Марселькка трагедија у свима својим узбудљивим и тешким појединостима, „Политика” 9486 (14.10.1934), s. 6.

${ }^{24}$ Ibidem.

25 Tajemnica spisku na króla Aleksandra i min. Barthou, „Ilustrowany Kuryer Codzienny” 283 (12.10.1934), s. 1.

${ }^{26}$ Ostatnie chwile króla Aleksandra i min. Barthou, „Dziennik Poznański” 233 (11.10.1934), s. 2. 


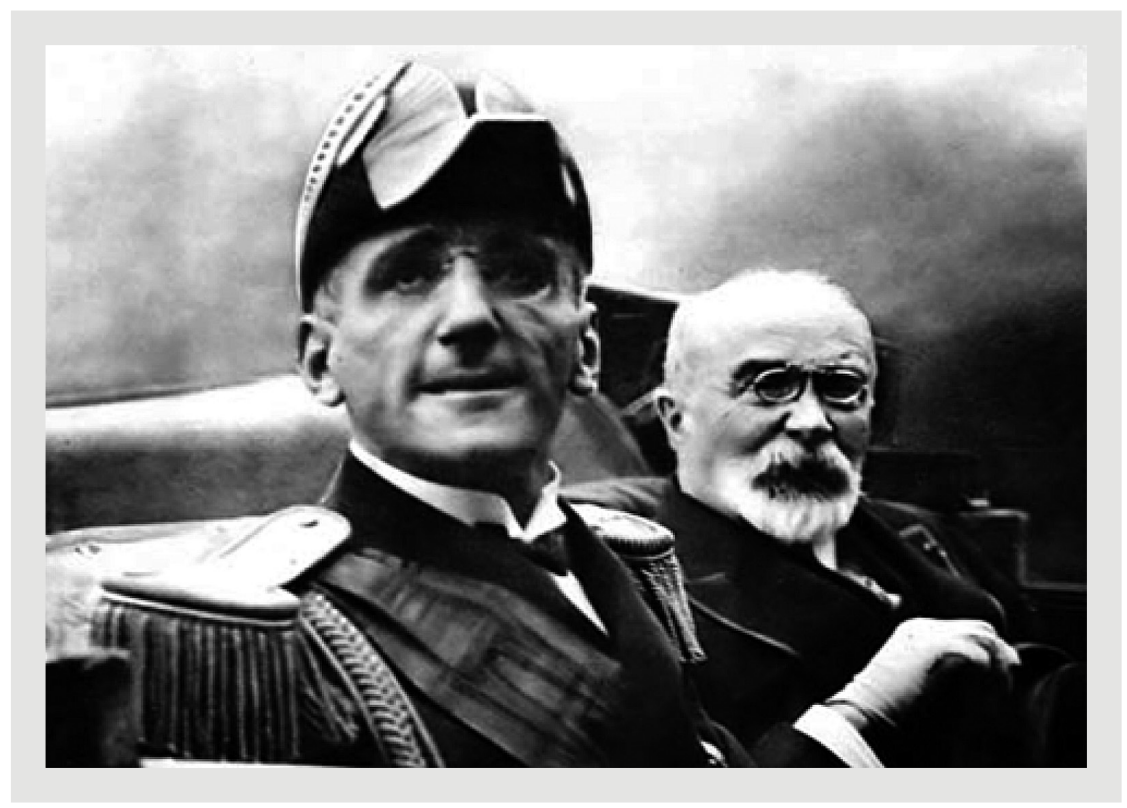

1. Król Aleksander I i Louis Barthou na chwilę przed zamachem w Marsylii 9 października 1934 r., za: Arhiv Jugoslavije w Belgradzie, bs., Краљ Александар и Луј Барту неколико тренутака пре атентата у Марсељь, 9 октобар 1934

Zamach został przeprowadzony około godziny 16.20, mniej więcej dziesięć minut przed planowanym złożeniem wieńca pod pomnikiem przy bulwarze La Corniche. Monarcha odniósł rany postrzałowe lewej ręki, ramienia i prawej łopatki. Śmiercionośny pocisk przebił ciało króla po prawej stronie klatki piersiowej i dotarł do wątroby. Król Aleksander I, krwawiący z ust i konający na tylnym siedzeniu samochodu, do ostatniego tchu miał otwarte oczy ${ }^{27}$. Z uwagi na wielkie zamieszanie monarchę zamiast do szpitala przewieziono na najbliższy posterunek policji, gdzie miano mu udzielić pomocy. Akcją ratunkową kierował dr Cammenar ${ }^{28}$. Monarcha utracił wszelkie funkcje życiowe około godziny 17.05, a więc trzy kwadranse po zamachu ${ }^{29}$. Jednak jego ciało znajdowało się $\mathrm{w}$ agonii już kilka chwil po zamachu. Według ministra Bogoljuba Jewticza ostatnie słowa wyszeptane przez króla brzmiały: „Strzeż mnie Jugosławio”, choć niewykluczone, iż mogło to być „Strzeżcie Jugosławii” ${ }^{30}$.

27 Престоница је с тубавлу и оданошћу дочекала свога младог Кральа, „Политика” 9486 (14.10.1934), s. 5.

${ }^{28}$ Imię nieustalone.

${ }^{29}$ L'Assassinat du roi Alexandre..., s. 3.

30 Przekład z języka serbskiego nie rozstrzyga wątpliwości w tej kwestii, a inne źródła na przemian cytują dwie podane tutaj wersje. Jakkolwiek było, słowa te, w każdym z tych dwóch wariantów, odzwierciedlały szczerą miłość króla Aleksandra I do Jugosławii. Zob. Ж. Петровска, op. cit. 
Interesująco zabrzmiał prasowy opis pierwszych chwil po zgonie monarchy, gdy jego ciało spoczywało na posterunku policji. Tekst został zredagowany przez „Ilustrowaną Republikę", która powołała się na źródła francuskie:

Z chwilą, kiedy doktorzy stwierdzili zgon, złożono jego zwłoki na kanapie, przykrywając je trójkolorowym sztandarem. Ręce króla są złożone na piersiach. Twarz spokojna, ale całkowicie pozbawiona krwi. W sali pogaszono wszystkie światła elektryczne, zostawiając tylko dwie zapalone świece. Po obu stronach stoi straż honorowa. Dywan przed zwłokami jest zasypany kwiatami. W sąsiednim pokoju słychać szloch starego kamerdynera królewskiego. Jest to człowiek, który poświęcił całe swoje życie wychowaniu młodego księcia Aleksandra i wraz z nim przeszedł wszystkie koleje w czasie wielkiej wojny. W sali sąsiedniej znajdują się dziennikarze serbscy, którzy godzinę temu z entuzjazmem witali króla. Wszyscy mają łzy w oczach ${ }^{31}$.

$\mathrm{Na}$ miejscu zamachu zginął szofer Berteleni, zaś minister Louis Barthou zmarł około godziny 17.40 na stole operacyjnym publicznego szpitala w Marsylii. Początkowo spekulowano, że dyplomata francuski mógł zginąć od kuli policjanta strzelającego do zamachowca, ale wkrótce ponad wszelką wątpliwość stwierdzono, że minister zmarł w wyniku rykoszetu kuli zamachowca, która była mierzona w kierunku monarchy. Szef dyplomacji francuskiej poniósł śmierć w rezultacie nadmiernego upływu krwi, co było skutkiem niedbalstwa służb ratunkowych, które zlekceważyły odniesione przezeń rany. Barthou osobiście zatrzymał jakiś pojazd, a następnie udał się nim do wspominanego szpitala ${ }^{32}$. Operacja dyplomaty miała dramatyczny przebieg - amputowano mu lewą rękę, w wyniku czego doszło do rozległego krwotoku. Pomimo wysiłków lekarzy Barthou zmarł, choć nawet przy zabiegu amputacji nie stracił przytomności, ciągle dopytując się o stan zdrowia króla Aleksandra I. Załamanie przyszło, gdy doszło do krwotoku. Wtedy też Barthou wypowiedział swoje ostatnie słowa: „Cierpię bardzo”, po czym stracił przytomność i zmarr ${ }^{33}$.

Tymczasem ciężko ranny generał Georges przeżył zamach. Na łamach „Ilustrowanej Republiki” poinformowano, że życie generałowi uratował order przypięty do jego munduru na wysokości serca. Spośród wielu odznaczeń, którymi mógł poszczycić się generał Georges, tego dnia zaprezentował serbski Order św. Sawy, którego materiał był na tyle mocny, iż zmienił kierunek wystrzelonego pocisku ${ }^{34}$. To właśnie generał Georges wraz z szoferem Bertelenim próbowali zapobiec zabójstwu, wdając się w szamotaninę z zamachowcem. W wyniku zamieszania od kul policjantów marsylskich zginęło też co najmniej sześć osób, a konkretnie

${ }^{31}$ Król Aleksander Jugosłowiański zamordowany, „Ilustrowana Republika” 278 (10.10.1934), s. 2.

${ }^{32}$ Minister Barthou mógł być uratowany, „Ilustrowana Republika” 281 (12.10.1934), s. 2.

${ }_{33}$ Ostatnie chwile króla Aleksandra..., s. 2.

${ }^{34}$ Order uratowat życie gen. George'a, „Ilustrowana Republika” 281 (12.10.1934), s. 2. 
panowie Armellin, Dupre, Durbec, Faris oraz pani Dumazert i jej syn ${ }^{35}$. Ponadto życie stracił co najmniej jeden z policjantów ${ }^{36}$.

Pierwszym mieszkańcem Marsylii, który rzucił się w pościg za zamachowcem, był człowiek o nazwisku Pelicier. To właśnie on powalił oszołomionego zabójcę na ziemię, a następnie wymierzył mu kilka ciosów. Policja marsylska dotkliwie pobiła Peliciera, uznając, że był on wspólnikiem zamachowca, a następnie skuła go w kajdanki i odprowadziła na przesłuchanie, gdzie poddano go torturom. Kilka dni później wyjaśniło się, że Pelicier nie miał nic wspólnego z zamachowcem. Nieszczęśnik natychmiast po zwolnieniu z aresztu w stanie ciężkim trafił do szpitala. Policja marsylska - ta sama, która go pobiła i torturowała - wyraziła wtedy wdzięczność dzielnemu Marsylczykowi za odważne zachowanie. O przeprosinach w każdym razie zapomniano ${ }^{37}$.

\section{Kim był zamachowiec?}

Autorem zamachu był Bułgar Włado Czernozemski, będący od 1922 r. wielokrotnym zabójcą, więziennym recydywistą i regularnym członkiem Wewnętrznej Macedońskiej Organizacji Rewolucyjnej. Na początku lat 30. XX w. Czernozemski podjął też aktywną współpracę z chorwackimi, rewolucyjnymi terrorystami, tj. ustaszami, zajmując się głównie szkoleniem zabójców w węgierskim Janka Puszta ${ }^{38}$. Wbrew temu, co napisał Meysztowicz, zamachowiec nie zmarł na miejscu zbrodni. Po oddaniu strzałów został uderzony szablą przez pułkownika Piolleta, postrzelony przez jednego z policjantów, a następnie skatowany na ich oczach przez wściekły tłum. Policja dała przyzwolenie ludowi na dokonanie samosądu, ale zmasakrowany Czernozemski przeżył lincz. Zamachowiec próbował też popełnić samobójstwo strzałem w usta, ale w zamieszaniu wytrącono mu broń ${ }^{39}$.

Niedługo po zamachu francuskie służby specjalne próbowały przesłuchać Czernozemskiego. Zamachowiec nie był w stanie wypowiedzieć słowa, a jego twarz została zmasakrowana do tego stopnia, że późniejsza identyfikacja nastąpiła na podstawie tatuażu symbolizującego jego przywiązanie do WMRO - trupiej czaszki z inicjałami organizacji ${ }^{40}$. Czernozemski zmarł około godziny 20:00 tego

${ }^{35}$ Краль Александар I погинуо је јуче по подне у Марсету као жртва злочиначког атентата, „Политика”, 10.10.1934, nr 9482, s. 3; Престоница је с тьубавтьу..., s. 5; L’Assassinat du roi Alexandre..., s. 3.

36 Ibidem.

37 Marsylczyk, który rzucił się na zabójcę, „Ilustrowana Republika” 282 (13.10.1934), s. 1.

38 И. Гаджев, История на българската емиграция в Северна Америка, София 2003, s. 259; Внатрешна македонска револуционерна организација - Демократска партија за македонско национално единство, http://vmro-dpmne.org.mk (dostęp: 5.03.2014).

39 Ibidem.

40 Tatuaż rozciągał się na długości około $5 \mathrm{~cm}$, ozdobił go napis „Wolność albo śmierć”, Morderca jest obywatelem czeskim, narodowości chorwackiej, „Dziennik Poznański” 233 (11.10.1934), s. 2. 


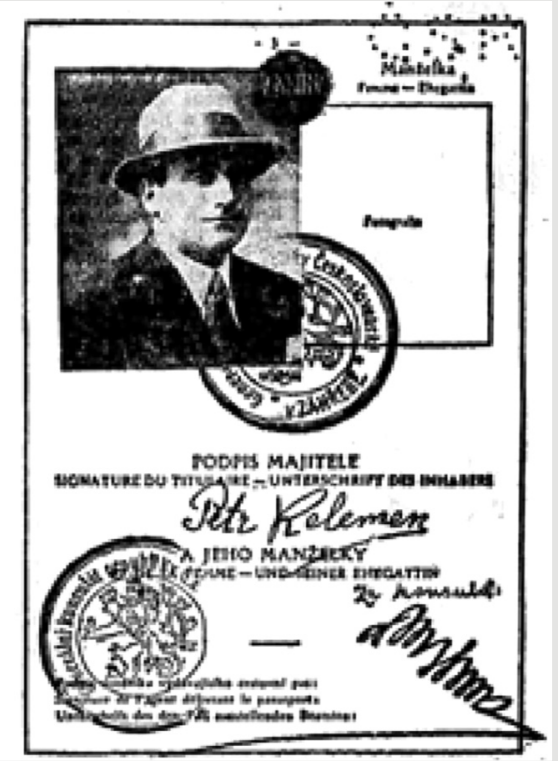

2. Jedna ze stron fałszywego paszportu, którym posługiwał się Włado Czernozemski, za: Марсељька трагедија у свима својим узбудливим и тешким појединостима, „Политика” 9486 (14.10.1934), s. 6 samego dnia, w którym dokonał zama$\mathrm{chu}^{41}$. Według Žakliny Petrowskiej policjanci podczas przesłuchania w marsylskim biurze bezpieczeństwa w wyjątkowo brutalny sposób torturowali półprzytomnego zamachowca, co przyspieszyło jego zgon $^{42}$. Stan Czernozemskiego został potwierdzony w relacji "Ilustrowanego Kuryera Codziennego", w której, powołując się na korespondenta wiedeńskiego, stwierdzono: „Twarz jest zupełnie zmiażdżona, tak, że nie może być zidentyfikowana" ${ }^{43}$.

Podczas rewizji u Czernozemskiego, oprócz wspominanej broni znaleziono jeszcze pistolet marki Walther, dwie bomby, kompas oraz 1700 franków francuskich. Ustalono, że zamachowiec przebywał we Francji od 29 września 1934 r. - najpierw w Paryżu, a następnie w pobliżu Marsylii, w odległości około $30 \mathrm{~km}$ od miasta. W dniu zamachu bułgarski morderca spożył dużą ilość alkoholu ${ }^{44}$. Czernozemski - znany też pod prawdziwym imieniem i nazwiskiem jako Weliczko Dimitrow Kerin lub pod pseudonimem Włado Szofer - przybył do Marsylii, posługując się fałszywym paszportem wystawionym przez konsulat czechosłowacki w Zagrzebiu na nazwisko Peter Kelemen ${ }^{45}$. To tej osobie początkowo przypisywano dokonanie zamachu, ale już 11 października 1934 r. na łamach „Politiki” ustalono, że nikt o takich personaliach nie istnieje $\mathrm{e}^{46}$.

Kierownik konsulatu czechosłowackiego w Zagrzebiu stwierdził, że jego placówka nigdy nie wydała paszportu na nazwisko Kelemen. Zadeklarował jednak pomoc w wyjaśnieniu wszelkich kwestii formalnych ${ }^{47}$. Wkrótce okazało się, że

${ }^{41}$ Краль Александар I..., s. 3.

42 Ж. Петровска, op. cit.

43 Tajemnica spisku na króla Aleksandra..., s. 1.

${ }^{44}$ Morderca miał wspólników, „Dziennik Poznański” 234 (12.10.1934), s. 1.

${ }^{45} \mathrm{~W}$ paszporcie zamachowca w rubryce zawód wpisano „kupiec”, Tajemnica spisku na króla Aleksandra..., s. 1.

46 У Загребу не постоји ни трговаи, ни трговина Петра Келемена, нити ико човека под тим именом познаје, „Политика” 9483 (11.10.1934), s. 10.

47 Morderca króla i min. Barthou - kto on?, „Ilustrowana Republika” 280 (11.10.1934), s. 2; Po zamachu w Marsylji, „Gazeta Lwowska” 242 (12.10.1934), s. 3. 
numer paszportu odpowiada dokumentowi wystawionemu byłemu żołnierzowi Legii Cudzoziemskiej, który nazywał się Anton Wawrina. Właściciel paszportu przebywał w Jugosławii niedługo przed marsylskim zamachu i właśnie wtedy zgubił paszport ${ }^{48}$.

Tak więc kiedy w kolejnych numerach „Politiki” wspominano o zamachowcu, wciąż posługiwano się nazwiskiem Kelemen, ale pisano je w cudzysłowie. Po raz pierwszy dane Czernozemskiego, wraz z fotografią jego twarzy i charakterystycznym tatuażem, opublikowano na łamach „Politiki” 17 października $1934 \mathrm{r}$. Prawdziwą tożsamość zamachowca udało się ustalić dopiero po przeprowadzeniu ekshumacji zwłok, w której uczestniczyła jego żona, Karniszewa - urodzona w Bułgarii kobieta, na której ciążyły podejrzenia o popełnienie kilku morderstw na Bałkanach ${ }^{49}$.

\section{Pierwsze godziny po zamachu}

Atmosfera w Marsylii w nocy z 9 na 10 października 1934 r. była przygnębiająca. Mieszkańcy tego portowego miasta głośnio krzyczeli i protestowali: „Marseille est déshonorée!" 50 . Domagano się szybkiego odnalezienia organizatorów zamachu i wznoszono hasła antyrządowe. Również lokalna prasa marsylska grzmiała przeciwko rządowi francuskiemu. Ekipie Gastona Doumergue’a przypisano częściową winę za śmierć monarchy jugosłowiańskiego. Główny argument, który był w tej kwestii podnoszony, wiązał się z obowiązującym we Francji prawem azylu dla emigrantów. Prasa domagała się zniesienia tego prawa lub co najmniej zaostrzenia kontroli dla cudzoziemców przybywających do Francji ${ }^{51}$. To również prasa marsylska wezwała władze miasta do postawienia królowi jugosłowiańskiemu pomnika, będącego symbolem przyjaźni francusko-jugosłowiańskiej². Później fundusze na realizację tego pomysłu gromadził wybitny francuski marszałek Louis Franchet d'Esperey ${ }^{53}$. Podobne demonstracje ludu i prasy dało się zauważyć w Paryżu, gdzie szczególnym obiektem ataków był minister spraw wewnętrznych Francji, Albert Sarraut ${ }^{54}$. Polityk podał się do dymisji 14 października $1934 \mathrm{r}$. Tego samego dnia

\footnotetext{
${ }^{48}$ Ibidem.

49 Дефинитивно је утврђен идентитет марселстког убице, „Политика” 9489 (17.10.1934), s. 7.

50 W polskim tłumaczeniu: „Marsylia okryła się hańbą!”. J. Meysztowicz, op. cit., s. 79.

51 Demonstracje przeciw policji francuskiej, „Ilustrowana Republika” 280 (11.10.1934), s. 2.

52 Wyrok śmierci na króla Aleksandra, „Ilustrowana Republika” 281 (12.10.1934), s. 2.

53 Pomnik został wzniesiony w 1936 r. w Paryżu. Monument przedstawia króla Aleksandra I na koniu, a także stojącego po jego prawej stronie marszałka Louisa Francheta d'Espereya oraz po lewej stronie króla Piotra I. Zarówno za marszałkiem, jak i za królem znajdują się jeszcze po dwie niezidentyfikowane przeze mnie postacie. Wszystkie sprawiają wrażenie, jakby oddawały hołd królowi Aleksandrowi I. Autorem pomnika był Maxime Real del Sarte.

${ }^{54}$ Demonstracje przeciw policji francuskiej, „Ilustrowana Republika” 280 (11.10.1934), s. 2.
} 
zdymisjonowano ministra sprawiedliwości, Henry’ego Chérona, na którego silną presję wywarł minister wojny, marszałek Philippe Pétain ${ }^{55}$.

Według doniesień prasowych skutki zamachu w Marsylii katastrofalnie odbiły się na zdrowiu byłego prezydenta Francji, Raymonda Poincarégo, który 15 października 1934 r. zmarł w wieku 74 lat. Jego śmierć została bezpośrednio powiązana przez prasę z zabójstwem jugosłowiańskiego monarchy. Na łamach „Ilustrowanej Republiki" zacytowano oświadczenie, którego autorem był ktoś z najbliższego otoczenia zmarłego, byłego prezydenta: „Zamach marsylski, a w szczególności tragiczna śmierć króla Aleksandra i ministra Barthou do głębi wstrząsnęły Rajmundem Poincaré. Stan jego zdrowia do tego czasu nie budzący niepokoju, nagle pogorszył się [...]”56. Na łamach „Dziennika Poznańskiego” zgonu tego polityka początkowo nie wiązano $\mathrm{z}$ zamachem $\mathrm{w}$ Marsylii ${ }^{57}$, ale wkrótce i $\mathrm{w}$ tej gazecie opublikowano artykuł, który jednoznacznie świadczył, że były prezydent Francji załamał się w rezultacie zabójstwa monarchy ${ }^{58}$. Pod wpływem tych wszystkich wydarzeń wkrótce ustąpił rząd Gastona Doumergue'a, a przewodnictwo nad kolejnym gabinetem 8 listopada 1934 r. objął Pierre-Étienne Flandin ${ }^{59}$.

Przeobrażenia rządu francuskiego na przełomie października i listopada 1934 r. były najniższym wymiarem kary, jaki można było wymierzyć ekipie Gastona Doumergue'a. Wszakże cytowany uprzednio Meysztowicz zwrócił uwagę, że poselstwo jugosłowiańskie w Paryżu już wcześniej informowało francuskie władze lokalne i rządowe o niebezpieczeństwie zamachu, ale te ostrzeżenia zostały zlekceważone ${ }^{60}$. Pogłoski o możliwości zamachu na króla Aleksandra I krążyły nawet wśród oficerów kompanii honorowej przyjmującej monarchę w Marsylii. Świadczyła o tym informacja, którą jednemu z oficerów udzielił kolega, będący członkiem chorwackich kółek emigranckich: „Mają dokonać w Paryżu zamachu na króla Aleksandra z pomocą ręcznego karabinu maszynowego. Będzie wielu zabitych. Niech się pan wystrzega, aby znajdować się w pobliżu króla" ${ }^{61}$. Należy jednak pamiętać, iż cytowane informacje o możliwości zamachu na króla Jugosławii były wyłącznie spekulacjami, które dziś trudno udowodnić i zweryfikować.

Bezpośrednio przez wydarzeniami w Marsylii królowa Maria nalegała na męża, aby nie jechał do Francji. Świadkiem rozmowy pary królewskiej był służący króla Aleksandra I, który opisał ją następującymi słowami: „królowa Maria

55 Podczas posiedzenia Rady Ministrów Pétain stwierdził o obecnym na sali Chéronie: „Wszyscy w rządzie odczuwamy ciężar, którego już czas najwyższy się pozbyć”, Dramatyczna dymisja ministra Cherona, „Ilustrowana Republika” 284 (15.10.1934), s. 2.

56 Śmierć b. prezydenta Francji, r. Poincarego, „Ilustrowana Republika” 285 (16.10.1934), s. 1.

57 Rajmund Poincaré nie żyje, „Dziennik Poznański” 237 (16.10.1934), s. 3.

58 Dramat marsylski przyspieszył śmierć Poincaré'go, „Dziennik Poznański” 238 (17.10.1934), s. 3.

${ }^{59}$ Le cabinet Doumergue se retire, „Le Figaro” 313 (9.11.1934), s. 1.

${ }^{60}$ J. Meysztowicz, op. cit., s. 79.

61 Wyrok śmierci na króla Aleksandra, „Ilustrowana Republika” 281 (12.10.1934), s. 2. 


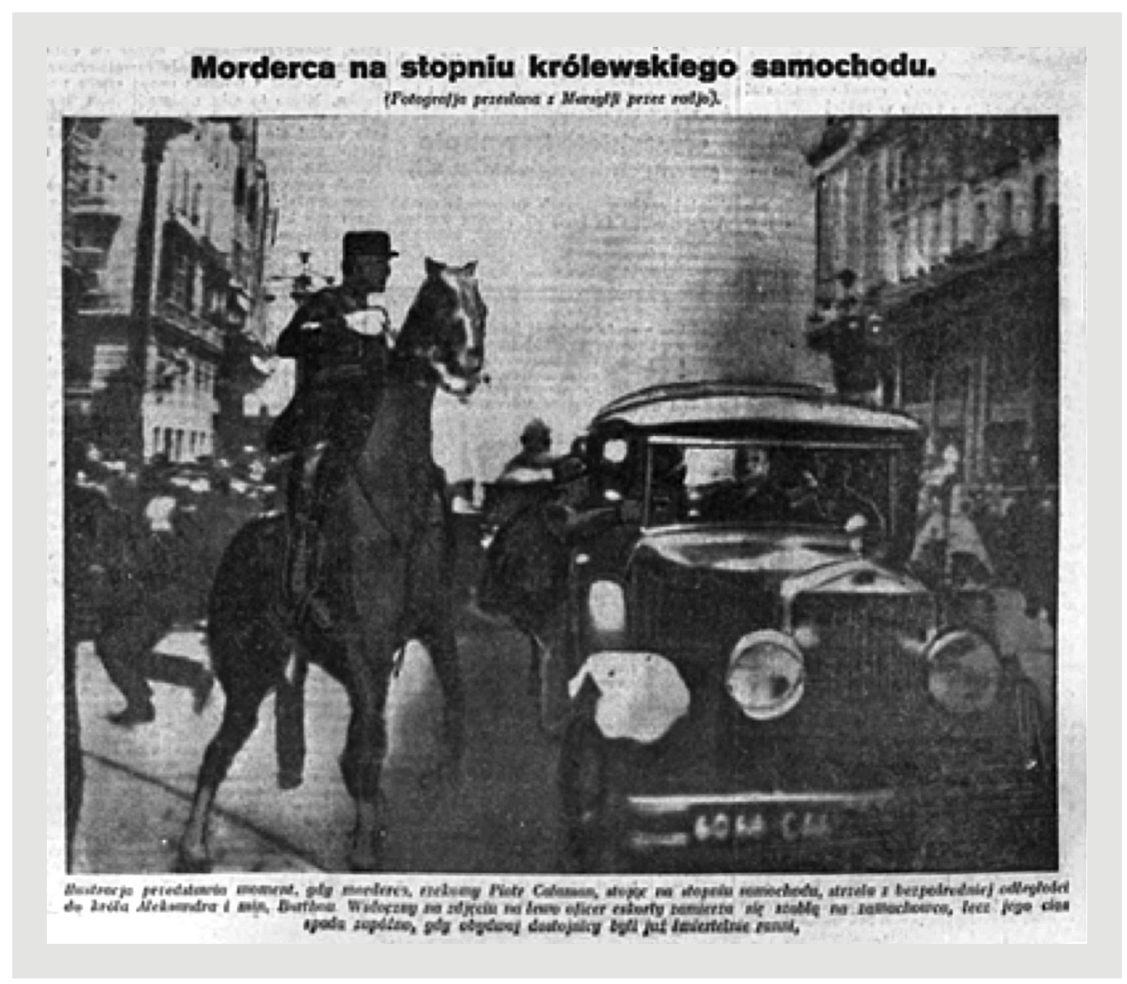

3. Zdjęcie ilustrujące moment zamachu w Marsylii, za: Tajemnica spisku na króla Aleksandra i min. Barthou, „Ilustrowany Kuryer Codzienny” 283 (12.10.1934), s. 1

[...] miała złe przeczucia, błagała i zaklinała na wszystko swego męża, aby zrezygnował z planu podróży do Paryża. Na wszystkie jednak jej zaklęcia [...] król odpowiedział zdecydowanie: Nie mogę zaniechać tej podróży, gdyż jest ona bardzo ważna dla polityki pokojowej na Bałkanach" ${ }^{62}$. Wyjazdowi monarchy do Francji próbował też zapobiec przewodniczący parlamentu jugosłowiańskiego, były burmistrz Belgradu i minister jugosłowiański, Kosta Kumanudi, który przerwał swą podróż do Stambułu, aby porozmawiać z monarchą. Zachowanie Kumanudiego było dziwne. Polityk w rozmowie z królem powoływał się na niepokojące przeczucie związane $\mathrm{z}$ wyjazdem monarchy do Francji. Król zlekceważył to ostrzeżenie, a wątek tzw. przeczuć Kumanudiego nie był później rozpatrywany w prasie jugosłowiańskiej ${ }^{63}$. Tymczasem niewykluczone, że w trakcie swej podróży Kumanudi spotkał się z pogłoskami o możliwości zamachu, które zostały rozpowszechnione przez emigrantów chorwackich.

\footnotetext{
${ }^{62}$ Królowa Marja błagała króla Aleksandra, aby nie wyjeżdżał do Francji, „Ilustrowany Kuryer Codzienny" 286 (15.10.1934), s. 5.

${ }^{63}$ Ibidem.
} 
Warto zauważyć, że część odpowiedzialności za przeprowadzony zamach ponoszą policja oraz inne służby mające zapewnić bezpieczeństwo podczas królewskiej wizyty. Oprócz wcześniej wspominanych kwestii, takich jak nieodpowiednie rozstawienie funkcjonariuszy na trasie przejazdu króla i zlekceważenie pogłosek o możliwości zamachu, na łamach "Głosu Porannego" poinformowano, że na placu w pobliżu giełdy nie został zgrupowany żaden patrol policji, a to przecież w okolicy tego miejsca doszło do zamachu ${ }^{64}$. Marsylskie służby, świadome swej nieudolności, skonfiskowały i ocenzurowały film, na którym ewidentnie można było dostrzec niedostatki w zabezpieczeniu wizyty monarchy jugosłowiańskiego ${ }^{65}$. Duże wątpliwości wzbudził też tajemniczy zgon autora filmu, Georges'a Mejata, który nastąpił sześć dni po dokonanym zamachu ${ }^{66}$. Można przypuszczać, że Mejat zaprotestował przeciwko konfiskacie i cenzurze filmu. Odpowiedzią policji na te protesty mogło być zlecenie jego zabójstwa, choć ta kwestia pozostaje wyłącznie $\mathrm{w}$ sferze spekulacji z uwagi na wystosowanie oficjalnego orzeczenia lekarskiego, iż Mejat zmarł śmiercią naturalną ${ }^{67}$.

Policja marsylska próbowała odwrócić od siebie uwagę, podając informację, że strzelała tylko w kierunku zamachowców, a przypadkowe ofiary strzelaniny były wynikiem strzałów oddanych przez współpracowników zamachowca, którymi otoczył się $\mathrm{w}$ trakcie zamachu ${ }^{68}$. Takie tłumaczenie zostało obalone przez ekspertyzę wystrzelonych pocisków, które pasowały albo do broni zamachowca, albo do pistoletów należących do skompromitowanych policjantów ${ }^{69}$. W każdym razie funkcjonariuszy próbowano bronić na łamach „Ilustrowanego Kuryera Codziennego”, gdzie stwierdzono iż: „Każdy tłum jest dżunglą, której nie może przeniknąć najbystrzejsze nawet oko policyjne"70, ale były to nieliczne próby pomniejszania odpowiedzialności policji za skutki zamachu.

Fala krytyki przetoczyła się nawet przez prasę francuską, w której często podnosiły się głosy, iż w tych służbach od wielu lat pracują awanturnicy, gangsterzy i łapownicy. Policji wytknięto też rażące nieprzygotowanie przejazdu króla Aleksandra I ulicami Marsylii. W formie retorycznej postawiono pytanie, dlaczego jugosłowiańskiemu monarsze nie towarzyszył szwadron konnicy, jak to zwykle bywa przy tego typu okazjach ${ }^{71}$. Trudno było zatem oczekiwać, że w tych okolicznościach rząd Gastona Domergue’a utrzyma się u władzy.

${ }^{64}$ Film stwierdza wine policji, „Głos Poranny. Dziennik polityczny, społeczny i literacki” 282 (12.10.1934), s. 3.

${ }^{65}$ Ibidem.

${ }^{66}$ Tajemniczy zgon kinooperatora, „Gazeta Lwowska” 245 (16.10.1934), s. 3.

67 Ibidem.

${ }^{68}$ Mordercę zastrzelili koledzy, „Głos Poranny. Dziennik polityczny, społeczny i literacki” 283 (13.10.1934), s. 1.

${ }^{69}$ Марсельска трагедија..., s. 6.

70 Znaczenie i skutki zamachu, „Ilustrowany Kuryer Codzienny” 283 (12.10.1934), s. 2.

${ }^{71}$ Gwattowne ataki na policję francuską, „Dziennik Poznański” 234 (12.10.1934), s. 2-3. 


\section{Czarne wrony nad trumną króla Aleksandra I}

Ciało monarchy znalazło się na pokładzie Dubrownika następnego dnia po zamachu. Pożegnaniu Aleksandra I towarzyszyła posępna atmosfera. Na posterunku policji, gdzie spoczywało ciało króla, generał Souchez ${ }^{72} \mathrm{w}$ towarzystwie siedmiu oficerów złożył mu ostatni hołd. Następnie po południu 10 listopada 1934 r. marsylską ulicą Canebière ruszył kondukt żałobny, na którego czele znaleźli się prezydent Francji, Albert Lebrun, królowa Maria ${ }^{73}$ oraz inni obecni na miejscu członkowie rodziny Karadziordziewiczów, a także ministrowie francuscy i przedstawiciele armii francuskiej ${ }^{74}$. Konduktowi towarzyszyły dźwięki hymnów Francji i Jugosławii ${ }^{75}$.

Meysztowicz tak opisał pogrążoną w żałobie ludność Marsylii, która żegnała zastrzelonego króla:

[...] gdy na pokładzie Dubrownika ustawiono trumnę okrytą jugosłowiańskim sztandarem, z wieży kościoła Notre-Dame-de-la-Garde, na wzgórzu dominującym nad miastem po wschodniej stronie Starego Portu odezwał się olbrzymi ośmiotonowy dzwon, słyszany tylko w wyjątkowych okolicznościach, i tysiące głów zwróciło się ku lśniącemu w słońcu na szczycie wieży złoconemu, prawie dziesięciometrowemu posągowi Madonny, jakby z niemym wyrzutem, iż nie uchroniła Marsylii od sromotnej, w odczuciu jej synów, chociaż nie zawinionej przez nich samych, odpowiedzialności za śmierć skrytobójczą króla Aleksandra ${ }^{76}$.

Kontrtorpedowiec z ciałem monarchy na pokładzie opuścił port w Marsylii około godziny 16.25. Eskortę okrętu stanowiły dwa kontrtorpedowce francuskie i dywizjon kontrtorpedowców jugosłowiańskich. Kiedy Dubrownik znalazł się na Adriatyku, doszło do jego postoju, ponieważ brytyjska flota śródziemnomorska pragnęła oddać hołd władcy jugosłowiańskiemu. Dowódca okrętu wyraził na to zgodę. Ostatecznie Dubrownik przypłynął do Splitu wczesnym rankiem 14 października 1934 r. pomiędzy godziną 5.00 a $6.00^{77}$. Ciało monarchy powitała delegacja żałobna, na czele której stanął stryj monarchy, książę Arsen, a także członkowie rządu i przedstawiciele armii. Według szacunków

72 Imię nieustalone.

${ }^{73}$ Królowa zemdlała, gdy dowiedziała się o śmierci króla. Następnie przybyła do Marsylii z Dijon, gdzie według pierwotnego planu miała oczekiwać króla. W niektórych gazetach poinformowano, że królowa Maria była w stanie błogosławionym i wskutek wzruszenia utraciła dziecko, ale te informacje nie zostały nigdzie potwierdzone. Powiadomienie królowej wdowy, „Dziennik Poznański” 233 (11.10.1934), s. 2; Komplikacje polityczne na Bałkanach, „Ilustrowana Republika” 280 (11.10.1934), s. 2.

${ }^{74}$ Ostatnia podróż króla Aleksandra do ojczyzny, „Ilustrowana Republika” 280 (11.10.1934), s. 1.

75 Po zamachu w Marsylji, „Gazeta Lwowska” 242 (12.10.1934), s. 1.

76 J. Meysztowicz, op. cit., s. 81.

77 Разарач „Дубровник” ноћи и отаибину мртво тетьо Кральа Александра, „Политика” 9483 (11.10.1934), s. 1. 
"Ilustrowanego Kuryera Codziennego" w Splicie zebrało się ok. 100 tys. osób opłakujących króla ${ }^{78}$.

Po dokonaniu identyfikacji zwłok przez księcia Arsena i generalicję jugosłowiańską monarsze złożono hołd. Trumnę z jego ciałem ustawiono na nabrzeżu, odegrano hymn jugosłowiański, odprawiono modlitwy żałobne i rozpoczęto defiladę do dworca $\mathrm{w}$ Splicie ${ }^{79}$. Stamtąd trumna z ciałem monarchy była transportowana koleją. Najpierw do Zagrzebia, gdzie monarchę żegnało ok. 200 tys. Chorwatów, a następnie, 15 października 1934 r., do Belgradu ${ }^{80}$. Tego dnia trumna $\mathrm{z}$ ciałem monarchy została wystawiona na widok publiczny w sali recepcyjnej pałacu królewskiego. Ludność mogła modlić się i składać kondolencje $\mathrm{w}$ godzinach od 6.00 do 22.00 przez trzy kolejne dni ${ }^{81}$. Z tej możliwości korzystano nad wyraz aktywnie - do Belgradu przybywały niezliczone pielgrzymki żałobne z całego kraju ${ }^{82}$.

Rozpacz po stracie władcy okazywali przede wszystkim Serbowie. Częstym widokiem na ulicach stolicy jugosłowiańskiej były manifestacje ku czci monarchy, połączone z licznymi aktami głośnej rozpaczy i przeklinania zabójców króla ${ }^{83}$. Oprócz Belgradu liczne demonstracje zostały zorganizowane w Lublanie, Sarajewie, Skopje i Zagrzebiu, gdzie rozmaitymi wyzwiskami obrzucano Włochy i Węgry. Doszło do wielu zamieszek, w wyniku których m.in. poturbowano konsula włoskiego w Lublanie, zaatakowano konsulat czechosłowacki w Zagrzebiu, a także poważnie pobito kilku Włochów mieszkających na stałe na terytoriach chorwackich i słoweńskich ${ }^{84}$. W rezultacie tych zajść ucierpiały też sklepy żydowskie we wszystkich wymienionych miastach, a także w Osijeku, choć trudno dostrzec jakąkolwiek winę Żydów w kontekście zamachu lub jugosłowiańskich sporów politycznych. Można sądzić, że wskutek ówczesnej ogólnoeuropejskiej propagandy antysemickiej Żydzi zostali potraktowani jako wygodna możliwość odreagowania wszelkich negatywnych emocji ${ }^{85}$. Poza tym w Lublanie i Sarajewie doszło do innej absurdalnej sytuacji, albowiem protestujący głośno pomstowali na Chorwatów,

78 Żałobny powrót króla-zjednoczyciela Jugosławji do Ojczyzny, „Ilustrowany Kuryer Codzienny” 287 (16.10.1934), s. 2.

79 Zwłoki króla Aleksandra przybyly do Jugosławji, „Gazeta Lwowska” 245 (16.10.1934), s. 1.

${ }^{80}$ Непрекидан танаи, ожалошћеног народа дуж пруге од Сплита до Београда дочекивао је воз с ковчегом Кральа Ујединительа, „Политика” 9488 (16.10.1934), s. 1.

${ }^{81}$ Przysięga na wierność nowemu królowi, „Gazeta Lwowska” 243 (13.10.1934), s. 1.

82 Pielgrzymi z całej Jugosławji do trumny, „Ilustrowana Republika” 286 (17.10.1934), s. 4.

${ }^{83}$ Нема речи којима би ие могао описати бол народа, „Политика” 9487 (15.10.1934), s. 8.

${ }^{84}$ Skutkiem tego konsul włoski w Lublanie opuścił Jugosławię. Burzliwe manifestacje w Jugosławji, „Ilustrowana Republika” 281 (12.10.1934), s. 4; Demonstracje w Jugosławji, „Ilustrowana Republika” 282 (13.10.1934), s. 1; Antywłoskie demonstracje w Jugosławji, „Gazeta Lwowska” 244 (14.10.1934), s. 1.

85 Po schwytaniu i śmierci Czernozemskiego ujawniono, że zamachowiec był obrzezany z powodu choroby określanej fimozą. Upublicznienie tej informacji mogło być związane z nasiloną agresją narodów jugosłowiańskich wobec Żydów; Pawelicz i Kwaternik aresztowani, „Głos Poranny. Dziennik polityczny, społeczny i literacki” 289 (19.10.1934), s. 5. 
z których kilku nawet pobito, podczas gdy w chorwackim Zagrzebiu również domagano się znalezienia winnych śmierci króla Aleksandra ${ }^{86}$.

Pogrzeb monarchy odbył się 18 października 1934 r. w Belgradzie i Topoli. Oficjalne uroczystości rozpoczęły się o godzinie 8.00 w stolicy jugosłowiańskiej, kiedy to odprawiono nabożeństwo żałobne celebrowane przez patriarchę Serbskiego Kościoła Prawosławnego, Barnabę. W tym samym czasie we wszystkich innych miastach Królestwa Jugosławii rozpoczęły się nabożeństwa żałobne, które na ogół trwały do czasu zakończenia głównych ceremonii w Belgradzie i Topoli. O godzinie 9.00 kondukt żałobny wyruszył z katedry w Belgradzie na dworzec kolejowy w Belgradzie, skąd przewieziono ciało do Topoli ${ }^{87}$.

Na czele konduktu żałobnego znajdował się duży krzyż, za nim oddział kawalerii i sztandary wszystkich pułków jugosłowiańskich. Dalej szły oddziały wojsk rodzimych i obcych, za którymi kroczył mistrz ceremonii Barnaba otoczony rycerzami orderu Karadziordziewiczów oraz duchownymi, patriarchami i biskupami innych wyznań. Niezwykle wzruszającym uczestnikiem konduktu żałobnego był ulubiony koń monarchy prowadzony przez dwóch gwardzistów królewskich. Za rumakiem najwyżsi dowódcy armii jugosłowiańskiej nieśli insygnia królewskie. Dalej powoli sunęło około trzydziestu samochodów, które przewoziły wieńce od ludu i oficjeli, i dopiero za nimi zaprzęg czterech koni ciągnął skromną trumnę ze zwłokami króla. Za trumną szedł syn monarchy, Piotr, przyodziany w strój sokoła jugosłowiańskiego, jego matka, królowa Maria oraz wszyscy członkowie rodziny Karadziordziewiczów, następnie delegacje państw zagranicznych, a za nimi tłumnie zebrana ludność Jugosławii ${ }^{88}$.

Kolejna część uroczystości żałobnej rozpoczęła się o godzinie 13.00 w Topoli. Zanim kondukt żałobny dotarł koleją do ukochanego przez króla miasteczka, na trasie przejazdu rozgrywały się dramatyczne sceny. Tłumnie zebrani ludzie padali na kolana w pobliżu przejeżdżającego pociągu, w rękach trzymali płonące świece i śpiewali pieśni żałobne. Prowincjonalna Topola była zatłoczona tak, że liczba obecnych kilkakrotnie przekraczała populację miasteczka. Nabożeństwo żałobne zakończyło się o godzinie 13.45. Wtedy też trumnę z ciałem monarchy złożono w mauzoleum św. Jerzego na górze Oplenac ${ }^{89}$.

Król Aleksander I został więc pochowany tam, gdzie jego ojciec, dziadek, pradziadek i wielu innych przodków. Jego trumna została ustawiona pomiędzy trumnami króla Piotra I oraz księcia Aleksandra. Monarcha spoczął w mauzoleum jako Rycerski Król Aleksander I Jednoczący. Tę godność nadano mu pośmiertnie

\footnotetext{
${ }^{86}$ Burzliwe manifestacje w Jugosławji, „Ilustrowana Republika” 281 (12.10.1934), s. 4; Demonstracje w Jugosławji, „Ilustrowana Republika” 282 (13.10.1934), s. 1; Antywłoskie demonstracje w Jugosławji, „Gazeta Lwowska” 244 (14.10.1934), s. 1.

87 Wśród łkań i szlochu tysięcznych tłumów, „Dziennik Poznański” 241 (20.10.1934), s. 3; Zwłoki króla Aleksandra spoczęły w mauzoleum, „Gazeta Lwowska” 249 (20.10.1934), s. 1.

88 Ibidem.

${ }^{89}$ Ibidem.
} 


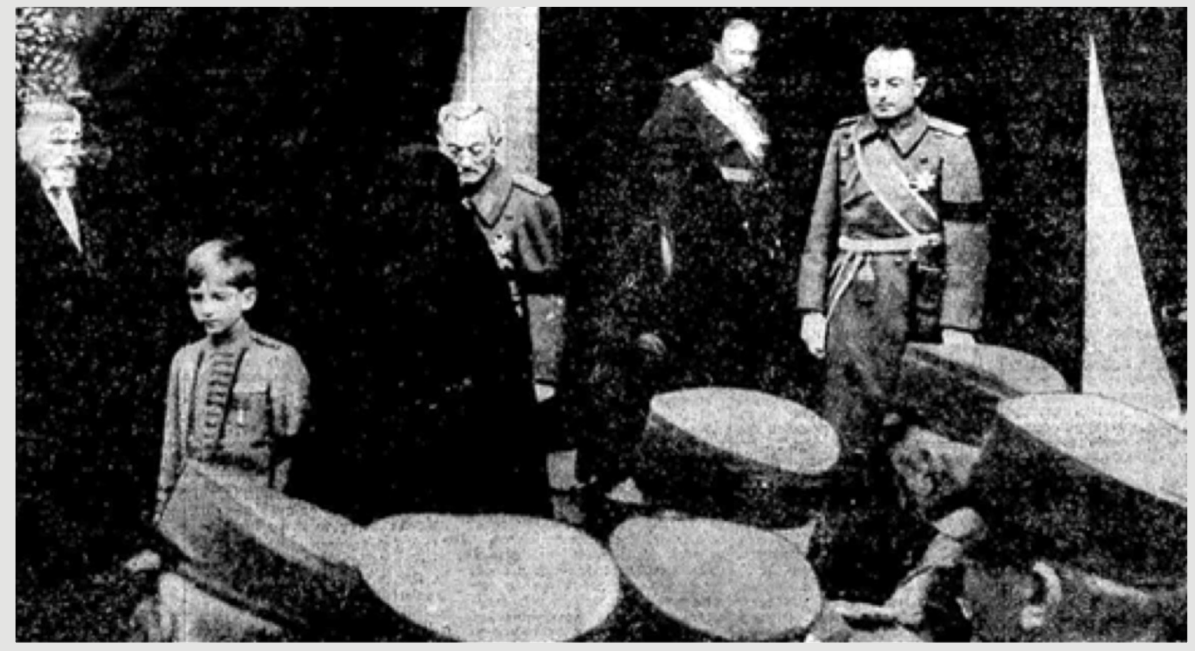

4. Wymowna fotografia zrobiona podczas pogrzebu króla Aleksandra I; od lewej: następca tronu, król Piotr II wraz odzianą na czarno matką, stryj zamordowanego monarchy książę Arsen, a także jego syn, kuzyn króla Aleksandra I, i rzeczywisty przywódca Królestwa Jugosławii po jego śmierci, książę Paweł; za: Престоница и душа Југославије, Београд, велики у своме болу, опростио ие јуче са својим витешким кратем ујединиетељьем, „Политика” 9491 (19.10.1934), s. 1

11 października 1934 r. na podstawie ustawy parlamentu ${ }^{90}$. Wtedy też podjęto decyzję o wprowadzeniu żałoby narodowej, która w Królestwie Jugosławii miała zakończyć się po roku, tj. 9 października 1935 r. ${ }^{11}$. Kwestią, która długo pozostawała w ukryciu przed jugosłowiańską opinią publiczną, był tatuaż króla - duży, jednogłowy orzeł z rozpostartymi skrzydłami, którego głowę zdobiła korona. Tatuaż zajmował dużą część klatki piersiowej monarchy. Jego znaczenie nawiązywało do heraldyki pruskiej ${ }^{92}$.

We wszystkich etapach głównej ceremonii pogrzebowej uczestniczyło około pół miliona ludzi, wśród których nie zabrakło liderów opozycji jugosłowiańskiej ${ }^{93}$. Niedługo po zamachu w Marsylii lider opozycjonistów słoweńskich, Anton Korošec stwierdził: „W momencie, kiedy cała Jugosławia opłakuje zgon swego wielkiego króla, wszystko winno być zapominane. Trzeba żyć i pracować dla Jugosławii”"94.

90 Намесници кралевске власти положили су пред народним представнистшом заклетву на верност Краљу Петру II, „Политика” 9484 (12.10.1934), s. 1.

91 Żałoba w Belgradzie, „Ilustrowany Kuryer Codzienny” 293 (24.10.1934), s. 15.

92 Gazeta Blic, http://www.blic.rs: V. MT., „Kralj Aleksandar imao tetovažu velikog orla” (dostęp: 7.03.2014).

${ }^{93} \mathrm{~W}$ ceremonii pogrzebowej uczestniczyli m.in. Anton Korošec i Ljubomir Davidović. Zabrakło przebywającego w więzieniu Mačka.

94 Wszystko powinno być zapominane, gdy Jugosławja płacze, „Ilustrowany Kuryer Codzienny” 287 (16.10.1934), s. 2. 
Te słowa odnosiły się do internowania Korošeca w maju 1932 r., którą to decyzję polityk upatrywał w bezpośredniej inicjatywie króla Aleksandra I. Jednak w obliczu jego śmierci wszelkie konflikty zostały zapominanie. W państwie spodziewano się również rychłej amnestii dla pozostałych polityków opozycyjnych. Warto również zauważyć, że krajowi opozycjoniści odcięli się od działalności emigrantów jugosłowiańskich.

Na pogrzeb monarchy przybyło też wielu czołowych polityków ${ }^{95}$. Polskę reprezentował ówczesny dowódca 2. Dywizji Kawalerii w Warszawie, generał Bolesław Wieniawa-Długoszowski wraz z towarzyszącymi mu oficerami, a także poseł polski w Belgradzie, Władysław Günther-Schwarzburg ${ }^{96}$. Warto dodać, że wielkie przejęcie wydarzeniami w Marsylii wyraziły polskie władze cywilne i wojskowe. Minister spraw zagranicznych Józef Beck, który w dniu zamachu, będąc gościem prezydenta Mościckiego, przebywał na polowaniu w Chodzieży, na wieść o zabójstwie króla Aleksandra I powrócił samolotem do Warszawy, po czym złożył kondolencje na ręce posła jugosłowiańskiego, Branko Lazarewicia. Następnego dnia szef polskiej dyplomacji złożył wyrazy współczucia również w ambasadzie francuskiej na ręce ambasadora Jules'a Laroche'a. W obu tych placówkach to samo uczynił szef gabinetu ministra spraw wojskowych, ppłk dypl. Adam Korwin-Sokołowski w imieniu marszałka Józefa Piłsudskiego, a także premier Leon Kozłowski w imieniu rządu polskiego. Zarówno w poselstwie jugosłowiańskim, jak i w ambasadzie francuskiej wystawiono księgi kondolencyjne, do których wpisywali się członkowie rządu, wojskowi wysokiego szczebla, posłowie, senatorowie i samorządowcy ${ }^{97}$. Uroczyste pismo kondolencyjne do Belgradu przesłał również metropolita warszawski i całej Polski, Dionizy ${ }^{98}$.

Niedługo po ceremonii pogrzebowej generał Bolesław Wieniawa-Długoszowski w wywiadzie udzielonym dla włoskiej gazety „La Stampa” wypowiedział się w następujących słowach: „Straszna wiadomość o śmierci króla wywołała w całej Polsce, a szczególnie w wojsku nieopisane wrażenie, gdyż była jak uderzenie gromu. Mówię

\footnotetext{
95 Na zdjęciach opublikowanych na łamach „Politiki” najbardziej w oczy rzucał się przewodniczący Reichstagu, twórca Gestapo, kilkakrotny minister III Rzeszy i premier Prus, Hermann Göring, fotografowany najczęściej w towarzystwie marszałka Francji Philippe’a Pétaina. To właśnie Göring z właściwą sobie megalomanią był autorem napisu na niemieckim wieńcu złożonym przy trumnie króla: „Swemu dawnemu bohaterskiemu przeciwnikowi, z bolesnym wzruszeniem - armia niemiecka”. Ponadto na zdjęciach „Politiki” rozpoznałem takich polityków i wojskowych, jak m.in. prezydent Francji Albert Lebrun, generał niemiecki Johannes Blaskowitz, król Rumunii Karol II, książę Kentu Jerzy, brytyjski admirał William Wordsworth Fisher, minister spraw zagranicznych Czechosłowacji Edvard Beneš, premier Czechosłowacji Jan Malypetr, minister spraw zagranicznych Turcji Tevfik Rüştü Aras, a także książę bułgarski Cyryl Koburg. Ponadto wielu wysokich przedstawicieli generalicji angielskiej, bułgarskiej, czechosłowackiej, greckiej, francuskiej, niemieckiej, tureckiej i innych.

96 Cała Europa składa hołd bohaterskiemu królowi, „Gazeta Lwowska” 247 (18.10.1934), s. 1.

97 W Warszawie, „Gazeta Lwowska” 242 (12.10.1934), s. 1.

98 Żałoba w Polsce, „Dziennik Poznański” 234 (12.10.1934), s. 3.
} 
to panu nie jako dziennikarzowi, lecz jakbym rozmawiał w kole swoich kolegów oficerów. Szacunek, jaki żywiliśmy dla króla Aleksandra, jako symbolu bohaterstwa, jest głęboko wyryty w naszych sercach. Jeżeli kto, to my, Polacy, w pierwszym rzędzie rozumiemy, co znaczy dla Jugosławii ta strata, ponieważ my wiemy, czym jest dla narodu jego wódz"99. Na terytorium Polski odbyły się też liczne akademie upamiętniające króla Aleksandra I jako bohatera wojennego i orędownika pokoju międzynarodowego ${ }^{100}$.

\section{Kto rządził Jugosławią po śmierci króla Aleksandra I?}

Po śmierci monarchy formalną władzę w państwie objął jego najstarszy syn, jedenastoletni wówczas Piotr. Taki stan został potwierdzony odezwą rządu premiera Nikoli Uzunowicza, wydaną 10 października 1934 r. i brzmiącą w następujący sposób: „Nasz wielki król Aleksander Pierwszy, dnia 9-go października o godzinie 16-ej padł w Marsylii ofiarą nikczemnego zamachu. Król-męczennik przypieczętował swą krwią dzieło pokoju, dla którego przedsięwziął swą podróż do sojuszniczej Francji. Zgodnie z art. 36 konstytucji najstarszy syn króla, Jego Królewska Mość Piotr Drugi, zasiada na tronie królestwa jugosłowiańskiego. Rząd, armia królewska i marynarka złożyli Jego Królewskiej Mości Piotrowi Drugiemu przysięgę wierności [...]"101. Następnie, 11 października 1934 r., na podstawie aktu wydanego podczas nadzwyczajnej sesji parlamentu, Piotr Karadziordziewicz został oficjalnie i w imieniu prawa ogłoszony królem Jugosławii ${ }^{102}$.

W dniu zamachu książę Piotr przebywał w Wiltshire, około $130 \mathrm{~km}$ od Londynu. Najstarszy syn monarchy od miesiąca pobierał edukację w elitarnej szkole Sandroyd, w której był kształcony z myślą o objęciu tronu jugosłowiańskiego ${ }^{103}$. Ten zaszczyt przypadł mu w udziale szybciej niż można było się spodziewać. Książę Piotr w dniu zamachu był wesoły i aktywny podczas szkolnej rozgrywki piłkarskiej ${ }^{104}$. O zamordowaniu ojca dowiedział się dzień po tragedii w godzinach porannych. Przykrą powinność poinformowania o śmierci monarchy wziął na siebie poseł jugosłowiański w Londynie o nazwisku Djuricz ${ }^{105}$, który jednocześnie zakomunikował Piotrowi, że tym samym obejmuje on tron jugosłowiański ${ }^{106}$. Reakcja księcia na tę wiadomość została opisana przez „Dziennik Poznański” w następujący sposób:

\footnotetext{
99 Deklaracja gen. Długoszowskiego, „Dziennik Poznański” 242 (21.10.1934), s. 3.

100 Żałobna akademja ku czci Króla-Bohatera, „Dziennik Poznański” 240 (19.10.1934), s. 4; Akademja żałobna ku czci Aleksandra I, „Ilustrowany Kuryer Codzienny” 287 (16.10.1934), s. 4.

101 Intronizacja 11-letniego króla Jugosławji, „Ilustrowana Republika” 280 (11.10.1934), s. 1.

102 Намесници кральевске власти..., s. 1.

103 Król umarł, niech żyje król!, „Dziennik Poznański” 233 (11.10.1934), s. 2.

104 Ibidem.

105 Imię nieustalone.

106 Intronizacja 11-letniego króla Jugosławji..., s. 1.
} 


\section{Dziecko na tronie}

Na urodziny ojca, króla Aleksandra, mały Piotruś zainstalował wlasnoręcznie dzwonek elektryczny

\begin{tabular}{|c|c|c|}
\hline 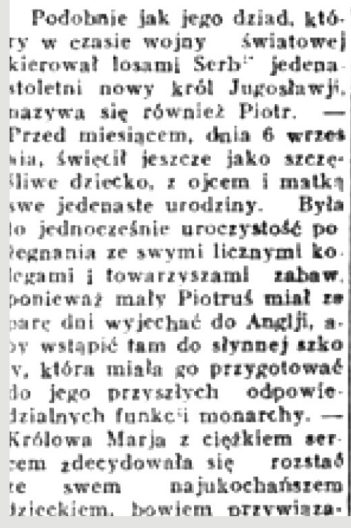 & & 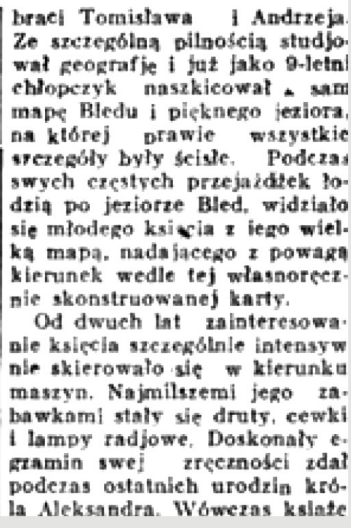 \\
\hline
\end{tabular}

5. Fragment ówczesnego artykułu o 11-letnim królu Piotrze II; za: Dziecko na tronie, „Głos

Poranny. Dziennik polityczny, społeczny i literacki” 282 (12.10.1934), s. 2

„Mały monarcha wykazał wyjątkowe opanowanie i cicho łkając, blady, wyszedł z towarzyszącym mu posłem jugosłowiańskim [...] do samochodu, w którym obok szofera zasiadł inspektor Scotland Yardu"107. W Londynie przebywała wtedy królowa Maria Rumuńska, babcia Piotra, która wraz z nim około południa opuściła koleją Anglię, udając się do Francji. Oprócz służb Scotland Yardu towarzyszyła im obstawa policjantów francuskich ${ }^{108}$.

Ówczesny burmistrz Belgradu, Milutin Petrowicz zwrócił się ze specjalnym apelem do mieszkańców, aby na chwilę zapomnieli o śmierci króla Aleksandra I, bowiem należy z godnością powitać jego następcę. W istocie po dotarciu do Jugosławii król Piotr II został żywiołowo powitany przez mieszkańców jugosłowiańskiej stolicy ${ }^{109}$. Następnie przysięgę na wierność monarsze Piotrowi II złożyli kuzyn Aleksandra I, książę-regent Paweł, senator i minister edukacji Radenko Stankowicz oraz ban banowiny Sawy, Iwo Perowicz ${ }^{110}$.

Rzeczywistą władzę w państwie objął książę regent Paweł i miał ją sprawować do czasu osiągnięcia pełnoletniości przez króla Piotra II. W „Głosie Porannym” Pawła

107 Król Piotr II przybyt do Paryża strzeżony bacznie przez policję, „Dziennik Poznański” 234 (12.10.1934), s. 2.

108 Ibidem.

109 Radosne powitanie, „Głos Poranny. Dziennik polityczny, społeczny i literacki” 283 (13.10.1934), s. 4.

110 Ibidem. 
Karadziordziewicza scharakteryzowano jako wytrawnego dyplomatę i poliglotę, niestroniącego od myślistwa, gry w golfa, lotnictwa i motoryzacji, będącego dotąd osobą niezaangażowaną w politykę. Po objęciu przez niego władzy spodziewano się amnestii dla polityków opozycyjnych, a także odsunięcia wojskowych od najważniejszych urzędów politycznych, ponieważ książę regent uważał, że wojskowi nie powinni mieszać się do polityki ${ }^{111}$. Tymczasem Stankowicz i Perowicz mieli zatroszczyć się o majątek zmarłego monarchy, a także o sprawy jego rodziny ze szczególnym uwzględnieniem wykształcenia jego synów. Wypełnił się zatem testament króla Aleksandra I, który został przezeń sporządzony przeszło dziesięć miesięcy przed zamachem, tj. $\mathrm{w}$ dniu 5 stycznia 1934 r. ${ }^{112}$

Na łamach „Głosu Porannego" zwrócono uwagę, że zaledwie na miesiąc przed zamachem, bo 6 września 1934 r., najstarszy syn króla Aleksandra I obchodził swoje jedenaste urodziny. Młody królewicz od dzieciństwa był dzieckiem poważnym, zafascynowanym geografią i budową maszyn. Z okazji 45. urodzin króla Aleksandra I przygotował mu samodzielnie wykonany dzwonek elektryczny. W „Głosie Porannym” podkreślono też duże przywiązanie królowej Marii do swoich trzech synów, którymi - w opinii cytowanej gazety - zajmowała się „[... jak zwykła śmiertelniczka" ${ }^{13}$. Królowa przykładała wielką uwagę do wychowania i edukacji swoich dzieci. We wspominanej gazecie zacytowano słowa, które wypowiedziała do Piotra podczas jednej z lekcji: „Czekają cię w życiu poważne zadania i jeżeli nie będziesz czegoś sam rozumiał, to nie będziesz mógł tego nakazać innym!"114. Po zamachu w Marsylii te słowa nabrały rzeczywistego, choć niespodziewanego wymiaru.

\section{Wokół poszukiwania inspiratorów zamachu}

Jeszcze przed przewiezieniem ciała monarchy do Belgradu, w Jugosławii zainicjowano śledztwo, które miało na celu ustalenie współpracowników Czernozemskiego. Wkrótce okazało się, że bezpośrednimi organizatorami zamachu byli ustasze, Ante Pawelicz i Eugen Dido Kwaternik. Akcję przeprowadzono w porozumieniu z przywódcą macedońskich rewolucjonistów, Iwanem Mihajłowem. Pod koniec sierpnia 1934 r. w rzymskim hotelu Continentale doszło do spotkania Pawelicza i Mihajłowa, podczas którego omówiono różne warianty zamachu na monarchę. Następnie we wrześniu 1934 r. spotkano się ponownie w Monachium, gdzie zostały

111 Monarcha i prawdziwy władca, „Głos Poranny. Dziennik polityczny, społeczny i literacki” 289 (19.10.1934), s. 2.

112 АЈ, Двор Краљевине Југославије, sygn. 74-23-40, Тестамент краља Александра I Карађорђевића о одређивағу старатель юеговој малолетној деии, 5 јануар 1934.

113 Dziecko na tronie, „Głos Poranny. Dziennik polityczny, społeczny i literacki” 282 (12.10.1934), s. 2.

114 Ibidem. 
opracowane dokładne szczegóły, włącznie z podjęciem decyzji o przekazaniu dużej sumy pieniędzy zamachowcom ${ }^{115}$.

Do akcji w Marsylii oprócz Czernozemskiego wyznaczono trzech pospolitych przestępców należących do organizacji chorwackich ustaszy. Byli nimi Mijo Kralj, Ivan Rajicz oraz Zvonimir Pospišil. Ta grupa posługiwała się we Francji paszportami otrzymanymi od węgierskiego wywiadu. Na początku października 1934 r. do bezpośredniej akcji w Marsylii został włączony Kwaternik, który w dniu zamachu dostarczył zamachowcom pieniądze, broń i amunicję, a także zapoznał ich z mapą planowanego przejazdu monarchy ${ }^{116}$. Kwaternik, ukrywający się pod nazwiskiem Kramer, powiedział wtedy do zamachowców: „Wiecie, co macie robić. Król dziś przyjeżdża do Marsylii. Strzelajcie"117. Wątpliwości wobec organizacji zamachu wyraził Pospišil, który nie chciał przypadkowo zranić lub zabić niewinnych ludzi. Kwaternik na tę wątpliwość zareagował nerwowo i wykluczył Pospišila z grona marsylskich zamachowców ${ }^{118}$.

Większość informacji o organizacji i okolicznościach zamachu uzyskały służby francuskie po szybkim schwytaniu Kralja, Rajicza i Pospišila ${ }^{119}$. Ustasze posługiwali się kilkoma fałszywymi paszportami ${ }^{120}$, ale $\mathrm{w}$ rezultacie brutalnego przesłuchania szybko złamali się w śledztwie i zaczęli ujawniać ważne informacje, a także zeznawać przeciw swoim zleceniodawcom ${ }^{121}$. Zamachowcy przyznali się, że w przypadku niepowodzenia akcji marsylskiej mieli dokonać zamachu w innych częściach Francji, albo w Szwajcarii, do której według ich informacji następnie miał udać się monarcha ${ }^{122}$. Jeszcze w Marsylii, w przypadku niepowodzenia Czernozemskiego, kolejne strzały miał oddać wmieszany w tłum Kralj. Jednak niedoszłemu zamachowcowi zabrakło odwagi i pośpiesznie uciekł $\mathrm{z}$ miasta ${ }^{123}$. W czasie rewizji w pokojach

115 Ухваћени су организатори марсетског атената емигранти Анте Павелић и Еуген Кватерник, „Политика” 9492 (20.10.1934), s. 3; Алтернатор су посши са Јанка Пусте y Мађарској, „Политика” 9492 (20.10.1934), s. 5.

116 Ibidem.

117 Morderca króla był Macedończykiem, „Gazeta Lwowska” 247 (18.10.1934), s. 1.

118 Ibidem.

119 Kralj i Rajicz dołączyli do Pospišila niedaleko granicy francuskiej w mieście Thonon-les-Bains. Cała trójka próbowała zbiec do Szwajcarii. W ramach szerokiej akcji poszukiwawczej policja w Marsylii i Paryżu dokonała wielu innych aresztowań, często wśród niewinnych ludzi. Schwytanie na granicy oraz Rewizje i aresztowania, „Głos Poranny. Dziennik polityczny, społeczny i literacki" 282 (12.10.1934), s. 1.

120 Każdy z zamachowców posługiwał się dwoma fałszywymi paszportami. Kralj wydanymi na nazwisko Malny i Willinger, w dwóch paszportach Rajicza widniały nazwiska Beneš i Sever, zaś w dokumentach Pospišila - Novak i Ungar. Ten ostatni był ścigany przez policję jugosłowiańską na podstawie wyroku o zabójstwo, w którym skazano go na karę śmierci. Tajemnica zamachu wyjaśniona!, „Głos Poranny. Dziennik polityczny, społeczny i literacki” 283 (13.10.1934), s. 1.

121 Ухваћени су организатори..., s. 3; Алтернатор су посии..., s. 5.

122 Emigranci chorwaccy - mordercami króla, „Ilustrowana Republika” 282 (13.10.1934), s. 1; Aresztowanie wspólnika Gergjewa, „Gazeta Lwowska” 246 (17.10.1934), s. 1.

${ }^{123}$ Malny miał strzelać z Kelemanem, „Ilustrowana Republika” 286 (17.10.1934), s. 3. 
zajmowanych przez zamachowców w różnych częściach Francji odnaleziono dwie bomby, trzy pistolety automatyczne, a także liczne chorwackie odezwy i pisma separatystyczne ${ }^{124}$.

W rezultacie zeznań współpracowników Czernozemskiego we Francji ruszyła szeroka fala aresztowań emigrantów bałkańskich. Policja ujęła m.in. byłego prominentnego polityka jugosłowiańskiego, Swetozara Pribiczewicza ${ }^{125}$, którego obciążyły zeznania Kralja. To właśnie on w dniu zamachu poinformował recepcjonistę hotelu w Aix-en-Provence, że udaje się do Pribiczewicza ${ }^{126}$. W domu byłego jugosłowiańskiego ministra spraw wewnętrznych odnaleziono dużą ilość pism nawołujących do podziału Jugosławii. Przesłuchiwano też osoby, z którymi kontaktował się Pribiczewicz ${ }^{127}$. Na posterunki policji w Marsylii, Paryżu i innych miastach Francji zgłaszali się liczni świadkowie, którzy z dużą gorliwością informowali o wszelkich podejrzanych cudzoziemcach w rejonie swojego zamieszkania $^{128}$. W rezultacie szerokiej akcji policji francuskiej zdołano ująć m.in. pośrednich uczestników zamachu na króla Aleksandra I, tj. żonę Kwaternika, Mariję Vondrać („Piękną Mariję”), a także oszusta, Mio Bzika. Oboje pełnili funkcje organizacyjne i wywiadowcze na miejscu w Marsyliii ${ }^{129}$.

Dziesięć dni po zamachu, tj. 19 października 1934 r., aresztowano ukrywających się w Turynie Pawelicza i Kwaternika. Obaj kategorycznie zaprzeczyli swojemu udziałowi w zamachu ${ }^{130}$. Pawelicz utrzymywał, że nigdy nie był w Marsylii, choć inaczej wskazywał posiadany przez niego paszport, który został wystawiony na Węgrzech ${ }^{131}$. Tymczasem Kwaternik stwierdził, że z pogardą odrzuca wszelkie zarzuty, a ostatnie dziesięć miesięcy spędził w Berlinie, co potrafi też udowodnić ${ }^{132}$. Francja zachowała się wtedy zupełnie niezrozumiale, bo rząd w Paryżu w ogóle

124 Ibidem.

125 Aresztowanie b. ministra Prybicewicza, „Gazeta Lwowska” 253 (25.10.1934), s. 1.

126 Morderca miał wspólników, „Dziennik Poznański” 234 (12.10.1934), s. 1.

127 Polityk był łatwym celem oskarżeń, gdyż w 1933 r. wydał w Paryżu antyrojalistyczną książkę Dyktatura króla Aleksandra (La dictature du roi Alexandre), a także stale utrzymywał udokumentowane kontakty z Serbami i Chorwatami mieszkającymi w Jugosławii. Pomimo tego, że Pribiczewicz był kawalerem Orderu Legii Honorowej, policja francuska podczas przesłuchania traktowała go źle. Według wspomnień polityka, opracowanych w 1990 r. przez Bogdana Krizmana, Dražena Budišę i Božidara Petrača, był on przetrzymywany w izolatce. Gdy okazało się, że nie ma nic wspólnego z zamachowcami, został zwolniony z tymczasowego aresztu, ale jednocześnie wydalony z Francji na podstawie „trudnych do udowodnienia” powiązań z organizatorami zamachu. Korzystając z tego casusu, z Francji usunięto wielu innych emigrantów jugosłowiańskich lub utrudniano im życie na tyle skutecznie, że sami decydowali się opuścić Francję. Pribiczewicz zmarł w Pradze w 1936 r.

128 Kelemen nie był macedończykiem?, „Dziennik Poznański” 235 (13.10.1934), s. 2.

129 Organizacja spisku, „Dziennik Poznański” 242 (21.10.1934), s. 3.

130 Aresztowanie Pawelicza i Kwaternika we Włoszech, „Gazeta Lwowska” 294 (10.10.1934), s. 3.

131 Pertraktacje o wydanie Pavelicza i Kvaternika, „Ilustrowany Kuryer Codzienny” 294 (23.10.1934), s. 3.

132 Pawelicz i Kvaternik wypierają się winy, „Gazeta Lwowska” 252 (24.10.1934), s. 3. 
nie wystąpił do Mussoliniego z pismem ekstradycyjnym ${ }^{133}$. Pismo takie jednakże wystosowała Jugosławia, ale Il Duce odmówił wydania Pawelicza i Kwaternika jugosłowiańskiemu wymiarowi sprawiedliwości ${ }^{134}$. Dyktator Włoch stwierdził wtedy, że wykazał maksimum lojalności wobec Jugosławii, gdyż rozkazał policji aresztować Pawelicza i Kwaternika, a przecież mógł ich tylko objąć nadzorem i kontrolą ${ }^{135}$.

Rząd Uzunowicza wyraził ubolewanie w stosunku do władz Francji, które miały sposobność przechwycenia organizatorów zamachu spod włoskiego protektoratu. Od tego momentu relacje pomiędzy Francją a Jugosławią ulegały stopniowemu oziębieniu. Na łamach „Gazety Lwowskiej” zauważono, że pod koniec października 1934 r. jugosłowiańscy członkowie wiodącej organizacji przyjaźni francusko-jugosłowiańskiej masowo wystąpili z jej szeregów, a w Skopje został zamknięty jeden z jej oddziałów $^{136}$. Na początku listopada 1934 r. stanowisko ministra sprawiedliwości utracił też sympatyk przyjaźni z Francją, Bożydar Maksimowicz ${ }^{137}$. Równocześnie ochłodziły się stosunki pomiędzy Francją a Małą Ententą, co zresztą już 11 października 1934 r. trafnie przewidziano na łamach „Ilustrowanej Republiki” ${ }^{138}$.

W ten sposób Pawelicz i Kwaternik pozostali we Włoszech, gdzie w komfortowych warunkach oczekiwali na proces, którego data została wyznaczona dopiero na 29 marca 1936 r. Natomiast tymczasowo aresztowani Kralj, Rajicz i Pospišil zostali skazani na karę dożywotniego pozbawienia wolności w rezultacie głośnego procesu, który odbył się 12 lutego 1936 r. we francuskim Aix-en-Provence, gdzie zamachowcy ukrywali się na dzień przed zabójstwem króla. Oskarżenie domagało się kary śmierci dla wspólników zamachowca, takie głosy podnosiły się również w społeczeństwie francuskim i jugosłowiańskim. Tymczasem proces wzbudził wiele kontrowersji. W Jugosławii powszechnie sądzono, że protektorat nad wspólnikami zamachowca objął sam Mussolini, który nie dopuścił do skazania ich na karę śmierci ${ }^{139}$. Ostatecznie Pospišil zmarł w niewyjaśnionych okolicznościach w więzieniu w Caen w 1940 r. i to samo rok później przydarzyło się Kraljowi w Fontevraud. Natomiast Rajicz z uwagi na pogarszający się stan zdrowia został zwolniony z więzienia 12 grudnia 1941 r., następnie powrócił do Chorwacji, gdzie zmarł w 1944 r. ${ }^{140}$

133 Ibidem.

134 АJ, Централни пресбиро Председниства Министарског савета КJ, sygn. 38-103-240, Оптужницом против атенатори и оганизатора марсељског атената.

135 Włochy wykazały maksimum lojalności, „Ilustrowany Kuryer Codzienny” 293 (24.10.1934), s. 15.

136 Zmiana nastrojów wobec Francji zaznacza się na terenie Jugosławji, „Gazeta Lwowska” 255 (27.10.1934), s. 1.

137 Jego miejsce zajął p.o. Dragutin Kojić. Устави и владе..., s. 273.

138 Komplikacje polityczne na Bałkanach, „Ilustrowana Republika” 280 (11.10.1934), s. 2.

139 АЈ, Централни пресбиро Председниства Министарског савета КJ, sygn. 38-104-241, Proces des assassins de S.M. Roi Alexandre Ier de Yougoslavie et de S.E.M. Louis Barthou ministre des affaires etrangères de la France, 5-12 Fevrier 1936.

140 АJ, Централни пресбиро Председниства Министарског савета КJ, sygn. 38-476-628, Извештај о пресуди убицама Крала Александра, 12 фебруар 1936; АJ, sygn. 74-1/619-658, 
Tymczasem w toku śledztwa zmarginalizowaniu uległa rola Iwana Mihajłowa. Wpływ na taki obrót spraw miała słabnąca pozycja organizacji macedońskich rewolucjonistów przy jednocześnie wzrastającym znaczeniu ustaszów. Osobą Mihajłowa interesowała się jednak prasa, w tym „Ilustrowana Republika”, która 11 października 1934 r. poinformowała, że jedną z przyczyn zamachu na króla Aleksandra I mogła być zemsta macedońskich rewolucjonistów. To przecież monarcha jugosłowiański w maju 1934 r. porozumiał się z premierem Bułgarii, Kimonem Georgiewem w sprawie usunięcia placówek WMRO z państwa bułgarskiego ${ }^{141}$. Na łamach „Ilustrowanej Republiki” zacytowano też wywiad z Mihajłowem, przeprowadzony w Stambule jakiś czas przed zamachem w Marsylii. Podczas rozmowy przywódca WMRO stwierdził, że jest idealistą i nacjonalistą, który dąży tylko do ustanowienia samodzielnej Macedonii. Na obcesową sugestię dziennikarza z Grecji odpowiedział z całą powagą, że macedońscy rewolucjoniści należą do organizacji z pobudek ideowych i nie pobierają żadnych pieniędzy, a ich działalność nie polega na zabijaniu ludzi ${ }^{142}$. Mihajłow ponadto stwierdził, że lekceważy wyrok śmierci wydany na niego przez sąd w Bułgarii, i dodał: „Śmierci się bać? Śmierci się nie boję! A śmierć w łóżku uważam za poniżającą" ${ }^{143}$. Przywódcę macedońskich rewolucjonistów widziano na przełomie września i października 1934 r. w Szwajcarii, ale wątek jego udziału w zamachu był podejmowany tylko w Jugosławii ${ }^{144}$.

Trudno jednoznacznie ustalić, jaką rolę w zamachu na króla Aleksandra I odegrali przedstawiciele innych państw europejskich. Poza dyskusją pozostaje fakt, że zamachowcy szkolili się $\mathrm{w}$ placówce terrorystycznej na terytorium Węgier. Dziennikarze „Politiki” postawili też śmiałą tezę, że uzyskali oni paszporty od węgierskiego wywiadu, na co przyzwolenie wyraził regent Węgier, Miklós Horthy oraz szef rządu węgierskiego, Gyula Gömbös. Tymczasem bez ryzyka można wysunąć hipotezę, że sam Mussolini popierał pomysł zabójstwa monarchy jugosłowiańskiego, o czym świadczyło ochranianie Pawelicza i Kwaternika przez Il Duce, a także stosowane przezeń naciski podczas procesu w Aix-en-Provence.

W październiku 1934 r. ruszyła silna fala oskarżeń ze strony Jugosławii, Francji i Czechosłowacji przeciwko władzom Węgier. Protestowały zarówno rządy tych krajów, jak i prasa. Domagano się śledztwa międzynarodowego na terytorium węgierskim w sprawie ustalenia powiązań z organizatorami zamachu w Marsylii. Wobec tych zarzutów i propozycji rząd Gömbösa reagował nerwowo, mówiąc o nieuzasadnionej polityce oszczerstw i próbie zrzucenia przez Francuzów odpowiedzialności moralnej za skutki zamachu, do którego doprowadziła nieudolność rządu Doumergue'a. Prasa węgierska zasugerowała, że o wiele większe skupisko

Винаверов извештај о процесу у екс ан провансу, 19 фебруар 1936; E. Kvaternik, Sjećanja i zapažanja 1925-1945: Prilozi za hrvatsku povijest, Zagreb 1995, s. 278-279.

${ }^{141}$ Komplikacje polityczne na Bałkanach, „Ilustrowana Republika” 280 (11.10.1934), s. 5.

142 Wywiad z przywódcą W.M.R.O, „Ilustrowana Republika” 290 (20.10.1934), s. 3.

143 Ibidem.

144 Ibidem. 
emigrantów jugosłowiańskich znajduje się we Francji, a na terytorium Węgier nie odnotowano działalności przeciwko Jugosławii, którą nad Sekwaną uprawiał choćby Pribiczewicz ${ }^{145}$. Skrytykowano też Czechosłowację, której zarzucono, że nie chodzi jej o wyjaśnienie okoliczności zabójstwa króla, tylko o realizowanie antywęgierskiej polityki ${ }^{146}$.

Węgierska linia obrony uległa później zmianom, gdy rząd Gömbösa w oficjalnym oświadczeniu poinformował, że żaden z zatrzymanych zamachowców nie był obywatelem węgierskim, a teren rzekomego obozu terrorystów w Janka Puszta został dokładnie przeszukany i objęty nadzorem, choć rzekomo znajdowała się tam wyłącznie ferma rolnicza. O inspirowanie kampanii oszczerstw oskarżono rządy Czechosłowacji i Francji, które - według Budapesztu - kosztem pogrążonej w żałobie Jugosławii chciały uruchomić proces destabilizacji Węgier ${ }^{147}$. W Czechosłowacji nieco ułatwiono obronę rządowi Gömbösa, gdy niespodziewanie w Pradze ukazało się kilka artykułów, w których znieważano króla Aleksandra I, zarzucając mu rozbicie pastwa jugosłowiańskiego i nieudolność w polityce zagranicznej ${ }^{148}$.

Kolejną odsłoną konfliktu między Węgrami a Małą Ententą i Francją stała się deklaracja o potrzebie umiędzynarodowienia śledztwa $\mathrm{w}$ sprawie zamachu w Marsylii, którą 20 października 1934 r. wydała rada Małej Ententy w porozumieniu z właściwymi członkami Ententy Bałkańskiej. To w praktyce oznaczało wezwanie do współpracy w celu ujawnienia wszystkich organizatorów i sprawców zamachu (w tym również państw-inspiratorów), aby w Europie nie dochodziło więcej do takich aktów terroru. Wyrażono też pełną solidarność z Jugosławią. Deklaracja miała bez wątpienia charakter antywęgierski. Pomimo tego, że w dokumencie nie wymieniono nazwy Węgier, bez trudu można było dostrzec, iż właśnie to państwo było jej adresatem ${ }^{149}$.

Tymczasem rząd Gömbösa naiwnie poinformował, że wszczął własne śledztwo na terytorium Węgier. Premier zapowiedział także, że udaje się z wizytą do „przyjacielskiego narodu polskiego" ${ }^{150}$, aby odizolować się od niesprawiedliwej kampanii oszczerstw wymierzonej przeciwko jego państwu. Ponadto Gömbös stwierdził, że: „W zbrodnię nie był wmieszany nie tylko rząd węgierski, lub jakiś rządowy lub urzędowy organ, ale nawet ani jeden obywatel węgierski”"151. W ramach Małej Ententy i Ententy Bałkańskiej nie dysponowano wówczas instrumentami ani też siłą nacisku, które mogłyby spowodować wszczęcie międzynarodowego śledztwa na terytorium Węgier.

145 Mała Ententa atakuje gwałtownie Węry, „Dziennik Poznański” 237 (16.10.1934), s. 2.

146 Wegry protestuja przeciw oszczerczej akcji, „Gazeta Lwowska” 247 (18.10.1934), s. 3.

147 Wegry protestuja przeciw oszczerczej kampanji, „Gazeta Lwowska” 249 (20.10.1934), s. 1.

148 Pogrzeb króla Aleksandra-Zjednoczyciela, „Gazeta Lwowska” 248 (19.10.1934), s. 1.

149 Deklaracja państw Małej Ententy i Ententy Bałkańskiej, „Gazeta Lwowska” 250 (12.10.1934), s. 1.

150 Premier Goemboes odpiera oszczercza kampanję skierowana przeciw Wegrom, „Gazeta Lwowska” 250 (21.10.1934), s. 1.

151 Ibidem. 


\section{Konkluzja}

Prawdziwi zleceniodawcy zabójstwa króla Aleksandra I nigdy nie zostali ujawnieni, choć poszlaki wskazują, że za tą zbrodnią stał Benito Mussolini, który sprawnie wykorzystał wrogość terrorystów chorwackich i macedońskich wobec monarchii Karadziordziewiczów. Kilka lat po śmierci władcy nastąpiło niespodziewane ocieplenie stosunków włosko-jugosłowiańskich, a w Królestwie Jugosławii stopniowo zaczęły się ujawniać wpływy faszyzmu i nazizmu. Ostatecznie, w rezultacie układów na linii Belgrad-Rzym-Berlin zawartych w okresie II wojny światowej doszło do skompromitowania dzieła politycznego króla Aleksandra I, a zarazem Jugosławii Karadziordziewiczów.

Zamordowanego monarchę należy ocenić niejednoznacznie. To przecież on zawiesił demokrację w swoim kraju i ogłosił się jego jedynym przywódcą. W każdym razie motywy króla Aleksandra I znacząco wykraczały poza idealistyczne i bezkrytyczne wyobrażenie o demokracji. Władca jugosłowiański na początku stycznia 1929 r. próbował ratować zjednoczone państwo przed realną możliwością rozbicia $\mathrm{w}$ rezultacie silnych tendencji separatystycznych, realizowanych niekiedy przy zastosowaniu metod terrorystycznych. Jego działaniom nie przyświecało więc dążenie do zdobycia lub utrzymania władzy, którą jako głowa państwa i tak posiadał, ale radykalna próba ratowania upadającego kraju. Tylko przywódca obdarzony cechami wybitnego męża stanu mógł podjąć ryzykowną decyzję o zawieszeniu podstawowych instytucji demokratycznych w państwie, a zarazem o ustanowieniu takiego reżimu, który nosiłby cechy kryzysowego, przejściowego i naprawczego.

Nie wszystkie cele króla Aleksandra I zostały jednak zrealizowane, ponieważ monarcha został haniebnie zamordowany w 1934 r. w Marsylii. Po jego śmierci państwo, które zbudował razem ze swoim ojcem i grupą wytrawnych polityków, znalazło się na rozdrożu pomiędzy utrzymaniem stabilizacji wewnętrznej a rekonfiguracją pozycji na arenie międzynarodowej. Sądzę więc, że Jugosławia Karadziordziewiczów nigdy nie otrząsnęła się po śmierci swego najważniejszego strażnika, a omówione w artykule okoliczności i konsekwencje dokonanego na niego zamachu świadczą o tym, że zamachowcom oraz ich inspiratorom chodziło właśnie o zniszczenie podstawowych instytucji tego państwa.

\section{Assassination of King Alexander I of Yugoslavia in the Light of Archival Press Articles}

\section{Abstract}

The article discusses the circumstances of the assassination of King Alexander I of Yugoslavia in October 1934 in Marseilles, France. On the basis of establishments, an analysis was made of the course of events associated with the assassination of King Alexander, including the political context of the crime, its direct reasons and also its first consequences for both Yugoslavia and the international arena. 
Within the broad spectrum of research issues involved in the assassination, there are some worthy of special attention, such as the organisation of King Alexander I's visit to France, characteristics of the assassin, internal situation in Yugoslavia after the monarch's death, the stand on the assassination of other states, as well as the investigation launched into the attack and an attempt to internationalise it.

The basic research material for the analysis was the Serbian and Polish interwar press, which makes not only a reliable, but often the only and fascinating source for the analysed events. In addition, the establishments presented in the essay have been verified by the - often insufficient - Polish and international literature on the subject, as well as by archival materials available in the Yugoslavia Archives in Belgrade.

The sum of the considerations makes it possible to discuss the circumstances of King Alexander I's assassination in great detail, impossible to find collected in one volume. At the same time it reveals the neglect of the contemporary French police and explains - at least in part - the plot to kill the Yugoslavian king.

\section{Убийство короля Александра I в свете архивных сообщений прессы}

\section{Аннотация}

В статье содержится обсуждение обстоятельств покушения на главу Королевства Югославия, совершенного 9 октября 1934 года в Марселе. На основе сделанных заключений анализу было подвержено развитие событий, связанных с убийством короля Александра I, включая изображение политического фона совершенного преступления, его прямых причин, а также ранних последствий для Югославии и международной среды.

В широкой группе исследовательских проблем можно отметить м. пр. вопрос способа организации дипломатического визита короля Александра I во Францию, характеристику цареубийцы, внутреннее положение Югославии после смерти монарха, точку зрения, изложенную иностранными правительствами, а также возбужденное вокруг убийства следствие и попытку его интернационализации.

Основным исследовательским материалом для проведенного анализа была сербская и польская пресса межвоенного периода, которая при посредстве своих корреспондентов или цитируя сообщения других отлично организованных европейских изданий, является достоверным, часто также единственным и одновременно захватывающим, источником в области обсуждаемых событий. Кроме этого, заключения, сделанные в статье, были верифицированы с доступной, хотя скромной и зачастую недостаточной, польской и иностранной литературой предмета, а также с архивными материалами, почерпнутыми в Югославском архиве в Белграде.

Сумма рассуждений сделала возможным подробное рассмотрение обстоятельств убийства короля Александра I, которых не удастся найти ни в одном другом труде. Это также разоблачение тогдашней халатности французской полиции, указание на предпосылки правовых решений и заодно сербских обычаев в случае смерти монарха, а также, по крайней мере частичное, разъяснение интриги, завязанной вокруг его смерти. 


\section{Bibliografia}

\section{1. Źródła}

\subsection{Materiały archiwalne}

Архив Југославије у Београду

Централни пресбиро Председниства Министарског савета КЈ

Служебне новине Краљевине Југославије

Збирка фотографија Двора Краљевине Југославије

Збирка међународних уговора

\subsection{Prasa}

„Blic”, http://www.blic.rs

„Dziennik Poznański”, 1934

"Gazeta Lwowska”, 1934

„Głos Poranny. Dziennik polityczny, społeczny i literacki”, 1934

„Ilustrowana Republika”, 1934

„Ilustrowany Kuryer Codzienny”, 1934

„Kurier Poznański”, 1934

„Le Figaro", 1934, http://www.lefigaro.fr

„Le Petit Parisien”, 1932, 1934

„Nowiny Codzienne”, 1934

„Nowy Kurier”, 1934

„Политика”, 1934

\section{Inne}

Batowski H., Między dwiema wojnami 1919-1939. Zarys historii dyplomatycznej, Kraków 2001. Bennett Ch., Yugoslavia's Bloody Collapse: Causes, Course and Consequences, New York 1995. Benson L., Jugosławia. Historia w zarysie, Kraków 2011.

Ćirković S., The Serbs, Wiley-Blackwell 2004.

Cox J. K., The History of Serbia, Greenwood 2002.

Djokić D., Elusive Compromise. A History of Interwar Yugoslavia, London 2007.

Essen A., Polska a Mała Ententa 1920-1934, Warszawa-Kraków 1992.

Felczak W., Wasilewski T., Historia Jugosławii, Wrocław 1985.

Garlicka A., Polska-Jugosławia 1934-1939. Z dziejów stosunków politycznych, Wrocław-Warszawa-Kraków-Gdańsk 1977.

Gašparič J., SLS pod Kraljevo Diktaturo: Diktatura kralja Aleksandra in politika Slovenske ljudske stranke v letih 1929-1935, Ljubljana 2007.

Giza A., Idea jugoslawizmu w latach 1800-1918, Szczecin 1992.

Giza A., Narodziny i rozpad Jugosławii, Szczecin 1994.

Glenny M., The Balkans 1804-1999: Nationalism, War and the Great Powers, London 1999.

Goebbels J., Dzienniki, t. 1: 1923-1939, t. 2: 1939-1943, wstęp i opracowanie E.C. Król, Warszawa 2013.

Janjatović B., Politički teror u Hrvatskoj 1918-1935, Zagreb 2002.

Judah T., The Serbs: History, Myth and the Destruction of Yugoslavia, New Haven 2009.

Lampe J. R., Yugoslavia as History. Twice There was a Country, Cambridge 2000.

Meier V., Yugoslavia: A History of Its Demise, London 1999. 
Meysztowicz J., Czas przeszły dokonany. Wspomnienia ze służby w Ministerstwie Spraw Zagranicznych w latach 1932-1939, przedmowa H. Batowski, Kraków 1984.

Pavličević D., Historia Chorwacji, Poznań 2004.

Payne S. G., A History of Fascism 1914-1945, Wisconsin 1996.

Perica V., Balkan Idols: Religion and Nationalism in Yugoslav States, Oxford 2002.

Petranović B., Istorija Jugoslavije, knjiga 1, Beograd 1988.

Podhorodecki L., Jugosławia. Dzieje narodów, państw i rozpad federacji, Warszawa 2000.

Robertson R., Roudometof V., Nationalism, Globalization, and Orthodoxy: The Social Origins of Ethnic Conflict in the Balkans, Greenwood 2001.

Singleton F., Twentieth-Century Yugoslavia, London 1976.

Stawowy-Kawka I., Historia Macedonii, Wrocław 2000.

The Royal Family of Serbia, www.royalfamily.org

Uniwersytet w Belgradzie, http://www.bg.ac.rs

V. MT., „Kralj Aleksandar imao tetovažu velikog orla”

Waldenberg M., Kwestie narodowe w Europie Srodkowo-Wschodniej, Warszawa 1992.

Walkiewicz W., Jugosławia, Warszawa 2009.

Внатрешна македонска револуционерна организација - Демократска партија за македонско национално единство, http://vmro-dpmne.org.mk.

Петровска Ж., „Атентатот во Марсеј”.

Македонска нација, http://www.mn.mk.

Михайлов, Иван. Избрани произведения, red. К. Андреев, София 1993.

Народно позориште у Београду, http://www.narodnopozoriste.rs.

Тюлеков Д., Обречено родолюбие. ВМРО в Пиринско 1919-1934, Благоевград 2001.

Konrad Sebastian Morawski, dr, politolog i historyk, autor artykułów naukowych i popularnonaukowych o dziejach Jugosławii oraz współautor podręcznika akademickiego dotyczącego problematyki bałkańskiej (konrad.morawski@wp.pl).

Konrad Sebastian Morawski, Ph.D., political scientist and historian, the author of numerous scientific and popular science articles on the history of Yugoslavia, and the co-author of a university textbook about the Balkans (konrad.morawski@wp.pl). 